Mongolian Geoscientist

Original article

\title{
Zircon U-Pb geochronology and geochemistry of granitic rocks in central Mongolia
}

\author{
Boldbaatar Dolzodmaa $^{1 *}$, Yasuhito Osanai ${ }^{2}$, Nobuhiko Nakano ${ }^{2}$, Tatsuro Adachi ${ }^{2}$ \\ ${ }^{1}$ Graduate School of Integrated Sciences for Global Society, Kyushu University, 744 Motooka, Nishi-ku, Fukuoka 819-0395, Japan \\ ${ }^{2}$ Division of Earth Sciences, Faculty of Social and Cultural Studies, Kyushu University, 744 Motooka, Nishi-ku, Fukuoka 819-0395, Japan \\ *Corresponding author: odmaa_kyushu@yahoo.com
}

\section{ARTICLE INFO}

Article history:

Received 08 January, 2020

Accepted 28 February, 2020

\begin{abstract}
The Central Asian Orogenic Belt had been formed by amalgamation of voluminous subduction-accretionary complexes during the Late Neoproterozoic to the Mesozoic period. Mongolia is situated in the center of this belt. This study presents new zircon $\mathrm{U}-\mathrm{Pb}$ geochronological, whole-rock major and trace element data for granitoids within central Mongolia and discusses the tectonic setting and evolution of these granitic magmas during their formation and emplacement. The zircon $\mathrm{U}-\mathrm{Pb}$ ages indicate that the magmatism can be divided into three stages: the 564-532 Ma Baidrag granitoids, the 269-248 and 238-237 Ma Khangai granitoids. The 564-532 Ma Baidrag granitoids are adakitic, have an I-type affinity, and were emplaced into metamorphic rocks. In comparison, the 269-248 Ma granitoids have high-K, calcalkaline, granodioritic compositions and are I-type granites, whereas the associated the 238-237 Ma granites have an A-type affinity. The 564-532 Ma Baidrag and 269 $-248 \mathrm{Ma}$ Khangai granitoids also both have volcanic arc-type affinities, whereas the 238-237 Ma granites formed in a post-collisional tectonic setting. These geochronological and geochemical results suggest that arc magmatism occurred at the 564-532 Ma which might be the oldest magmatic activity in central Mongolia. Between the Baidrag and the Khangai, there might be paleo-ocean and the oceanic plate subducted beneath the Khangai and produced voluminous granite bodies during the 269-248 Ma. After the closure of the paleo-ocean, the post collisional granitoids were formed at the 238-237 Ma based on the result of later granitoids in the Khangai area.
\end{abstract}

Keywords: I-type granite, adakite, A-type granite, Central Asian Orogenic Belt

\section{INTRODUCTION}

Mongolia is located within the central part of the Central Asian Orogenic Belt (CAOB), which is bounded to the north by the Precambrian Siberian craton and to the south by the Tarim and North China cratons (Badarch et al., 2002; Windley et al., 2007). The central part of Mongolia is also known as the Khangai region (including the Bayankhongor area) and records multiple orogenic and magmatic events between the early Proterozoic and Mesozoic (Takashi et al., 2000; Jahn et al., 2004). However, the geology of this region remains relatively poorly characterised, with previous studies focusing on only a small number of granitic rocks. This means that systematic and

(C) The Author(s). 2020 Open access This article is distributed under the terms of the Creative Commons Attribution 4.0 International License (https://creativecommons.org/licenses/by/4.0/), which permits unrestricted use, distribution, and reproduction in any medium, provided you give appropriate credit to the original author(s) and source, provide a link to the Creative Commons license, and indicate if changes were made. 
representative sampling and the associated analysis of these samples are needed to understand the tectonic processes that generated these voluminous granitoids, in addition to furthering our understanding of the tectonic evolution of the CAOB.

\section{GEOLOGICAL SETTING}

This study focuses on the Khangai region of Mongolia, which is divided from south to north into the Baidrag, Bayankhongor, Zag, and Khangai areas, all of which contain numerous exposed granitoids (Fig. 1). The Baidrag area is located to the southwest of the Bayankhongor ultramafic belt and contains schists, gneisses, marbles, and quartzites that are all thought to be derived from earliest Neoproterozoic sedimentary protoliths (Badarch et al., 2002; Zhang et al., 2015) that were metamorphosed during a Barrovian-type event. Metamorphic grades increase northwards and this metamorphic event occurred between ca. 562 and $533 \mathrm{Ma}$ (Zhang et al., 2015). The granitoids in this area were emplaced into these metamorphic rocks and have yielded Sensitive High-Resolution Ion MicroProbe (SHRIMP) and laser ablation inductively coupled plasma mass spectrometry (LA-ICP-MS) zircon U-Pb ages of $546.3 \pm 3.0$ and $514 \pm 10 \mathrm{Ma}$, respectively (Zhang et al., 2015; Jahn et al., 2004), indicating that this granitic magmatism occurred contemporaneously or slightly after the metamorphic event.

The Bayankhongor ultramafic belt is located between Baidrag to the south and Zag to the north, and is thought to represent a series of ophiolitic fragments (Badarch et al., 2002). It consists of a series of serpentinized ultramafic cumulates, gabbros, sheeted dikes, pillow lavas, and locally developed cherts and limestones (Fig. 1). The ophiolitic anorthosites, gabbros, and plagiogranites in this belt yielded SHRIMP zircon $\mathrm{U}-\mathrm{Pb}$ ages between $655 \pm 4$ and $636 \pm 6$ Ma (Jian et al., 2010).

The Zag area is located to the northeast of the Bayankhongor ultramafic belt and consists of highly deformed pelitic and psammitic chloritemica schists that have been metamorphosed under lower greenschist-facies conditions. The area also contains weakly metamorphosed, fine- grained, and interbedded siltstones, sandstones, and shales that contain rounded quartz grains, preserve sedimentary structures, and most likely represent a turbidite sequence (Fig. 1). The protoliths for the Zag schists are thought to be deep-water passive margin sedimentary units that overlie the Bayankhongor ophiolite, but are located beneath the sedimentary cover of the Khangai Basin (Badarch et al., 2002). Detrital zircon $\mathrm{U}-\mathrm{Pb}$ ages for the $\mathrm{Zag}$ schists yield a depositional age of $<445 \pm 6 \mathrm{Ma}$ (Kröner et al., 2011), whereas metamorphic white micas from the Zag metasediments yield $\mathrm{K}-\mathrm{Ar}$ ages of 454 $\pm 9,445 \pm 9$, and $395 \pm 20$ Ma (Jian et al., 2010).

Devonian and Carboniferous sedimentary rocks are widely distributed in the Khangai area (Fig. 1) and together constitute the Khangai-Khentii Basin (Tomurtogoo et al., 1998; Kelty et al., 2008; Purevjav and Roser, 2012). This basin is located within the central and northeastern parts of Mongolia and extends into Russia, where it forms the western end of the Khangai-KhentiiDaurian zone of the Mongol-Okhotsk Fold Belt (MOFB) (Zorin, 1999). These sedimentary rocks host voluminous early Permian and Triassic granitoids that are associated with large contact metamorphic aureoles (Orolmaa et al., 2008). Together these granitoids and sedimentary rocks form the NW-SE trending Khangai Mountains (Fig. 1). The sampling undertaken during this study was undertaken along a longitudinal traverse, yielding a total of 105 granitic samples (Fig. 1).

\section{Field occurrences and petrology}

564-532 Ma Baidrag granitoids

Fieldwork during this study identified Kfeldspar porphyritic biotite granite and redcolored K-feldspar porphyritic biotitehornblende granite units, with the latter either containing or free of mafic microgranular enclaves (MME; Fig. 2).

These granitic rocks were generally emplaced into and are in direct contact with metamorphic rocks that include garnet-biotite gneiss, amphibolite, and garnet-sillimanite-biotite gneiss units (Fig. 2a, d). However, the sharp boundaries between these units are not associated with significant contact 


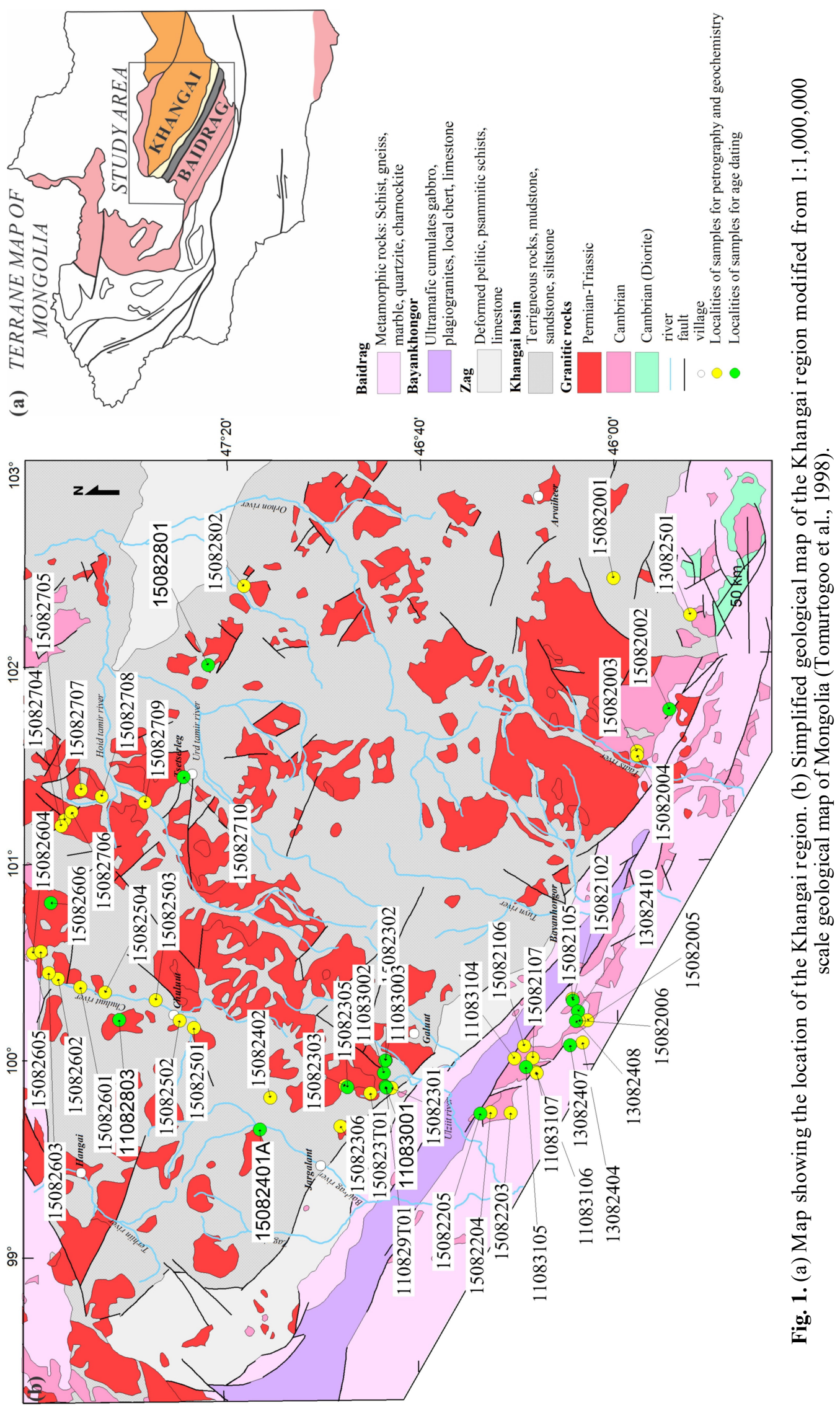



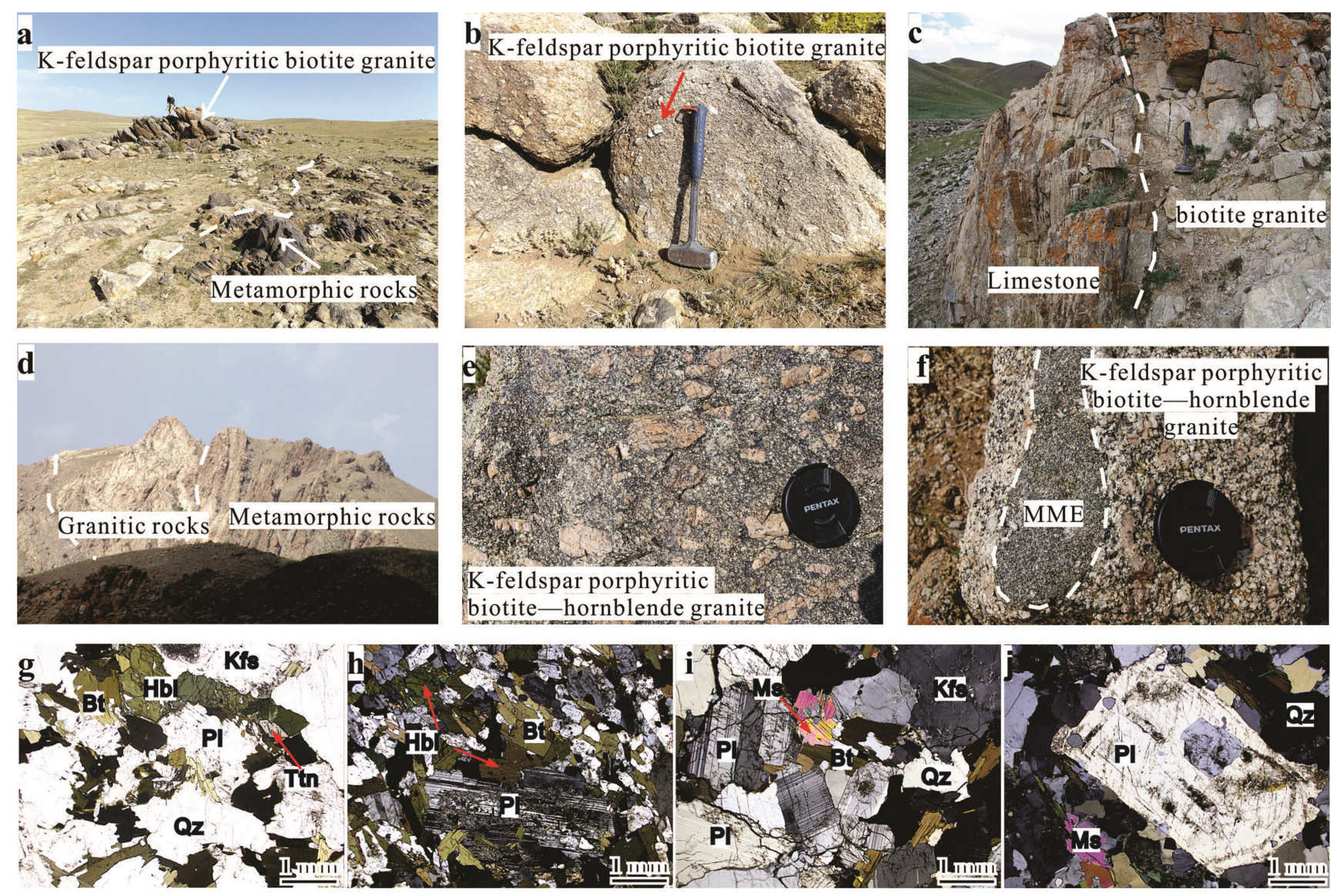

Fig. 2. Field setting and photomicrographs of representative analyzed samples in the Baidrag area. (a) Kfeldspar porphyritic biotite granite and metamorphic rocks (samples 15082105A, B), (b) K-feldspar porphyritic biotite granite (sample 15082105A), (c) Biotite granite in contact with limestone (sample 15082205A), (d) Granitic rock emplaced into metamorphic country rock, (e) Red-colored K-feldspar porphyritic biotite-hornblende granite (sample 15082102), (f) Red-colored K-feldspar porphyritic biotite-hornblende granite containing a MME (sample 15082106), (g) K-feldspar porphyritic biotite-hornblende granite (sample 15082102), (h) MME (sample 15082106C) within the K-feldspar porphyritic biotite-hornblende granite, (i) K-feldspar porphyritic biotite granite (15082105A),

(j) Biotite-muscovite granite (15082107B).

metamorphism, apart from skarn-type calcsilicates that are developed along the contact between the K-feldspar porphyritic biotite granite and limestone or weakly recrystallized marble units (Fig. 2c). The biotite granite is leucocratic and contains very large but variably sized K-feldspar (Fig. 2b). The K-feldspar porphyritic biotite-hornblende granite also contains very large K-feldspar, but this granite is more melanocratic than the biotite granite and the K-feldspar present in this unit is reddish to pinkish in color (Fig. 2e). The boundary between the Baidrag granitoids and Bayankhongor ultramafic belt is characterized by a red-colored K-feldspar porphyritic biotitehornblende granite that contains MME (Fig. 2f). Representative plutonic rocks from the Baidrag area (Fig. 2g-j) include K-feldspar porphyritic biotite-hornblende granite, K-feldspar porphyritic biotite granite, and biotite-muscovite granite units, with the K-feldspar porphyritic biotite-hornblende granites being divided into two types depending on the presence or absence of MME.

K-feldspar porphyritic biotite-hornblende granites (15082102 and 15082106B, Fig. 2g) contain hornblende, biotite, K-feldspar, plagioclase, and quartz along with accessory titanite, apatite, zircon, allanite, and opaque minerals. The accessory phases are both matrixhosted and present as inclusions within hornblende, biotite, and plagioclase. The MME (15082106C, Fig. 2h) within the K-feldspar 

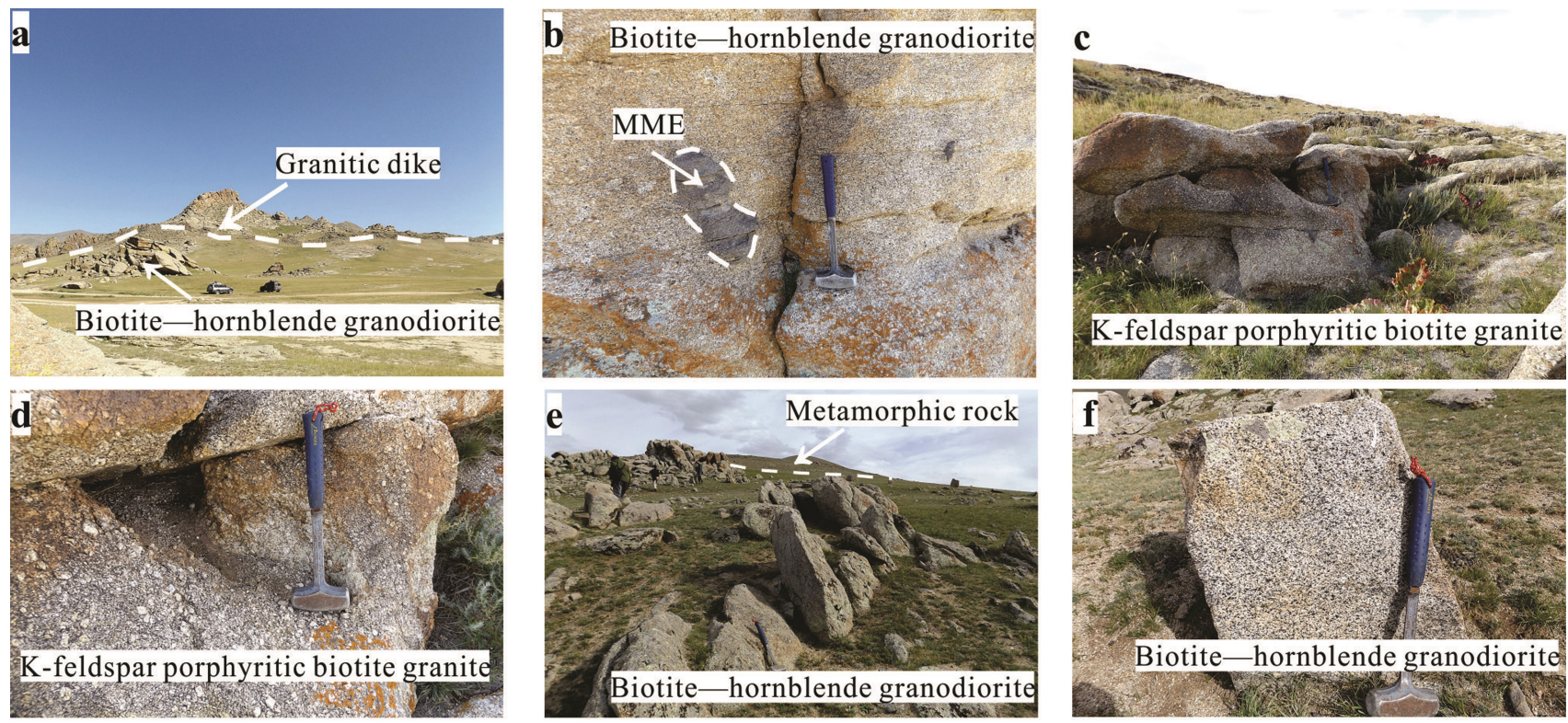

\section{g}
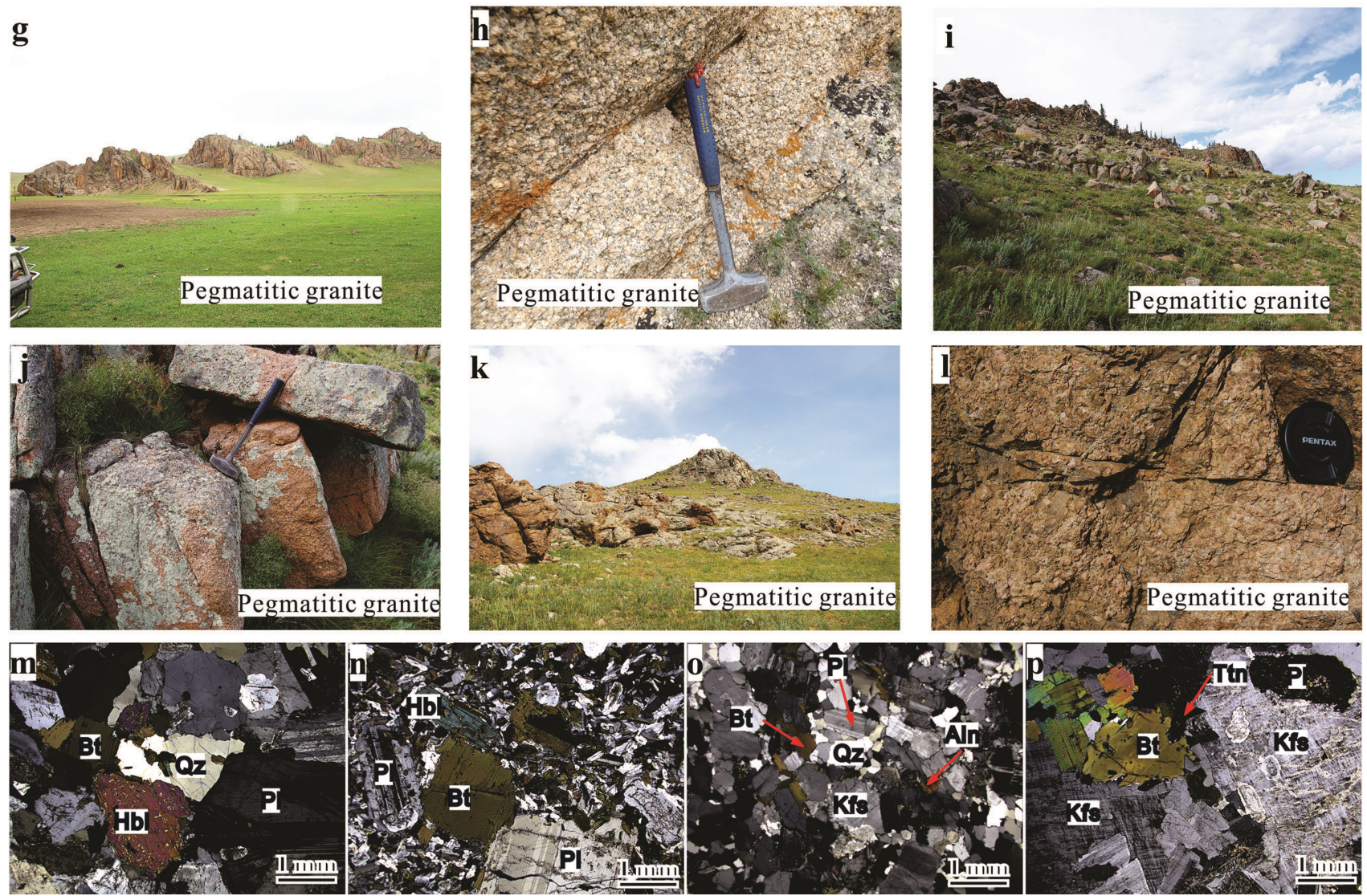

Fig. 3. Field setting of representative analyzed samples in the Khangai area. (a) Phaneritic biotite-hornblende granodiorite and granitic dike (samples 15082302A, B), (b) Phaneritic biotite-hornblende granodiorite containing MME (samples 15082302A, B), (c, d) K-feldspar porphyritic biotite granite (sample 15082306), (e, f) Phaneritic biotite-hornblende granodiorite and metamorphic rock (samples 15082603A, B), (g, h) Coarse-grained allotriomorphic pegmatitic granite (sample 15082504), (i, j) Red-colored coarse-grained allotriomorphic pegmatitic granite (sample 15082606A), (k-l) Coarse-grained allotriomorphic pegmatitic granite (sample 15082707), (m) Biotitehornblende granodiorite (sample 15082401A), (n) MME (sample 15082502C) within the biotite-hornblende granodiorite, (o) Biotite granite (sample 15082402A1), (p) Pegmatitic granite (sample 15082710). 
porphyritic biotite-hornblende granite (15082106A) contains phenocrystic plagioclase and relatively fine-grained minerals that contains the same minerals as the hosting $\mathrm{K}$ feldspar porphyritic biotite-hornblende granite.

K-feldspar porphyritic biotite granite (15082105A, Fig. 2i) contains biotite, Kfeldspar, plagioclase, quartz, and muscovite along with accessory apatite, zircon and opaque minerals. This granite is free of hornblende and accessory phases are both matrix-hosted and present as inclusions within biotite.

Biotite-muscovite granites (15082107B and 15082203, Fig. 2j) contain biotite, K-feldspar, plagioclase, quartz, and muscovite along with minor amounts of zircon.

\section{9-248 Ma Khangai granitoids}

The 269-248 Ma Khangai granitoids are dominated by fresh and undeformed phaneritic biotite-hornblende granodiorite and medium- to fine-grained biotite granite units. The southwestern part of the Khangai area is dominated by phaneritic biotite-hornblende granodiorite units that commonly contain MME and are crosscut by a granitic dike (Fig. 3a, b). The west-central part of the Khangai area contains phaneritic biotite-hornblende granodiorite units with MME and K-feldspar porphyritic biotite granite units (Fig. 3c, d). The central to northern parts of this area contain phaneritic biotite-hornblende granodiorite and medium-to fine-grained biotite granite units, whereas the majority of the northern part of this area contains phaneritic biotite-hornblende granodiorite units that have been emplaced into metamorphic country rocks, including granitic, garnet, and biotite-garnet gneisses (Fig. 3e, f).

Granodiorites and MME. Hypidiomorphic biotite-hornblende granodiorite samples from the Khangai area $(15082302 \mathrm{~A}, 15082401 \mathrm{~A}$, $11082803 \mathrm{~A}, 15082502 \mathrm{~A}, 15082502 \mathrm{~B}$, and 15082603B1/2, Fig. 3m) contain biotite, hornblende, plagioclase, K-feldspar, and quartz along with accessory titanite, apatite, zircon, allanite, and an opaque phase. The accessory phases are present as inclusions within hornblende, biotite, and plagioclase. The MME within the biotite-hornblende granodiorites (15082304B, 15082502C, and 15082603B2/2, Fig. 3n) contains porphyritic hornblende, biotite, and plagioclase within a fine-grained matrix that contains accessory titanite, apatite, allanite, and zircon, all of which are also present as inclusions within phenocrystic hornblende and biotite.

Granites. The K-feldspar porphyritic biotite granite (15082306) contains biotite, K-feldspar, plagioclase, and quartz along with minor amounts of titanite, apatite, allanite, zircon, and opaque minerals. The medium- to fine-grained biotite granite $(15082402 \mathrm{~A} 2,15082402 \mathrm{~A} 1$, 15082705, 15082709, and 15082002A, Fig. 3o) contains biotite, K-feldspar, plagioclase, and quartz along with minor amounts of titanite, allanite, zircon, and opaque minerals.

\section{8-237 Ma Khangai granitoids}

The central to northern parts of the Khangai area contain coarse-grained pegmatitic granites with crystals that are up to $2 \mathrm{~cm}$ in size (Fig. $3 \mathrm{~g}-1$ ).

Pegmatitic granites and granitic dikes. Coarsegrained pegmatitic granites (15082710, 15082504A, and 15082606A, Fig. 3p) are dominated by biotite, K-feldspar, quartz, and plagioclase along with minor amounts of titanite, zircon, allanite, apatite, and opaque minerals. The porphyritic granitic dike (15082302D) contains phenocrystic plagioclase and K-feldspar hosted by a fine-grained groundmass.

\section{METHODS}

All analyses were performed using instruments housed at Kyushu University, Fukuoka, Japan.

\section{LA-ICPMS U-Pb Zircon dating}

The analytical procedure used for zircon $\mathrm{U}-\mathrm{Pb}$ dating has been described in detail by Adachi et al. (2012b). Zircon crystals from the samples were separated and mounted in epoxy disc with $25 \mathrm{~mm}$ diameter and $4 \mathrm{~mm}$ thickness, following separation from powdered samples by panning with a beaker and watch glass then hand picking (Kitano et al., 2014). Internal textures and 
mineral inclusions of individual zircon crystals were observed using a scanning electron microscope (JEOL JED2140JSM-5301S) with a cathodoluminescence (CL) detector (GatanMiniCL). Zircon U-Pb dating was undertaken by LA-ICPMS using an Agilent $7500 \mathrm{cx}$ quadrupole ICPMS with a New Wave Research UP-213 laser. For U-Pb geochronology, abundance of the isotopes ${ }^{202} \mathrm{Hg},{ }^{204} \mathrm{~Pb},{ }^{206} \mathrm{~Pb},{ }^{207} \mathrm{~Pb},{ }^{208} \mathrm{~Pb},{ }^{232} \mathrm{Th}$, and ${ }^{238} \mathrm{U}$ were monitored during all analyses, with ablations performed using laser diameters of 25 to $40 \mu \mathrm{m}$. The integrated isotopic ratios were corrected against standard zircon Temora (417 Ma; Black et al., 2003), and the NIST SRM-611 glass standard was used to calculate $\mathrm{Th} / \mathrm{U}$ ratios. The standard zircon FC-1 (1099 Ma; Paces and Miller, 1993) was used to ensure consistency. All zircon data reductions and calculations were processed with the GLITTER software package (Griffin et al., 2008), using the analytical and calculation protocols for time-resolved analysis described by Jackson et al. (2004). Concordia diagrams were calculated using the Isoplot/Ex 4.1 software package (Ludwig, 2008).

\section{Geochemistry}

Whole-rock major $\left(\mathrm{SiO}_{2}, \mathrm{TiO}_{2}, \mathrm{Al}_{2} \mathrm{O}_{3}, \mathrm{TFe}_{2} \mathrm{O}_{3}\right.$, $\mathrm{MnO}, \mathrm{MgO}, \mathrm{CaO}, \mathrm{Na}_{2} \mathrm{O}, \mathrm{K}_{2} \mathrm{O}$, and $\mathrm{P}_{2} \mathrm{O}_{5}$ ) and trace elements (V, Cr, Co, Ni, Cu, Zn, Ga, Rb, $\mathrm{Sr}, \mathrm{Y}, \mathrm{Zr}, \mathrm{Nb}, \mathrm{Ba}$ ) were analyzed with a Phillips PW2400 wavelength dispersive X-ray fluorescence (WDXRF) spectrometer using fused glass beads (2:1 dilution of sample). Prior to fusion, all samples were heated at $900^{\circ} \mathrm{C}$ for 2.5 hours to remove volatiles, and to oxidize ferrous iron. The concentrations of rare earth elements (REEs) and five trace elements (Hf, $\mathrm{Ta}, \mathrm{Pb}$, Th, and $\mathrm{U}$ ) were determined by LAICPMS using an Agilent 7500cx quadrupole ICPMS with a New Wave Research UP-213 laser, and these analyses were made directly on the glass bead that had been used for XRF analysis. The analytical procedures and accuracy of the LA-ICPMS approach used during this study are given in Nakano et al. (2012). The analytical uncertainties are less than $5 \%$ of the concentration of each element.

\section{Zircon $\mathrm{U}-\mathrm{Pb}$ dating}

\section{RESULTS}

A total of 21 samples were dated, with sample locations shown in Fig. 1 and the results given in Table 1.

564-532 Ma Baidrag granitoids. Biotite granite sample $15082205 \mathrm{~A}$ yielded 18 concordant analyses from zircon rims and $\mathrm{a}{ }^{206} \mathrm{~Pb} /{ }^{238} \mathrm{U}$ age of $532.5 \pm 3.7 \mathrm{Ma}(\mathrm{n}=18)$ with a $\mathrm{Th} / \mathrm{U}$ value of 0.67 (Fig. 4a). A further three concordant analyses yielded ages of $943 \pm 28,1668 \pm 53$, and $1900 \pm 51 \mathrm{Ma}$ that reflect the ages of inherited zircon cores. Biotite-hornblende granite sample 15082102 yielded three discordant and subsequently discarded analyses and a further 11 concordant analyses that yielded a ${ }^{206} \mathrm{~Pb} /{ }^{238} \mathrm{U}$ age of $532.0 \pm 5.2 \mathrm{Ma}(\mathrm{n}=$ 11) with a $\mathrm{Th} / \mathrm{U}$ value of 0.59 (Fig. 4b). A single further concordant analysis yielded an age of $769 \pm 22 \mathrm{Ma}$, reflecting the presence of an inherited zircon core.

269-248 Ma Khangai granitoids. Biotitehornblende granodiorite sample 15082401A yielded eight discordant and excluded data and a further 13 concordant analyses that yielded a ${ }^{206} \mathrm{~Pb} /{ }^{238} \mathrm{U}$ age of $259.9 \pm 2.0 \mathrm{Ma}(\mathrm{n}=13)$ with a $\mathrm{Th} / \mathrm{U}$ value of 0.57 (Fig. 4c). A MME within a biotite-hornblende granodiorite (15082401C) yielded 10 concordant data and an associated ${ }^{206} \mathrm{~Pb} /{ }^{238} \mathrm{U}$ age of $257.5 \pm 2.7 \mathrm{Ma}$ with a $\mathrm{Th} / \mathrm{U}$ value of 0.15 (Fig. 4d). Biotite granite sample $15082002 \mathrm{~A}$ yielded eight concordant analyses and an associated ${ }^{206} \mathrm{~Pb} /{ }^{238} \mathrm{U}$ age of $248.7 \pm 3.1$ Ma with a $\mathrm{Th} / \mathrm{U}$ value of 0.81 (Fig. $4 \mathrm{e}$ ).

238-237 Ma Khangai granitoids. Pegmatitic granite sample 15082710 yielded 7 discordant and 16 concordant analyses, with the latter yielding a ${ }^{206} \mathrm{~Pb} /{ }^{238} \mathrm{U}$ age of $237.8 \pm 2.2 \mathrm{Ma}(\mathrm{n}=$ 16) with a $\mathrm{Th} / \mathrm{U}$ value of 0.73 (Fig. 4f). Granitic dike sample 15082302D contains zircons with rims that yielded a ${ }^{206} \mathrm{~Pb} /{ }^{238} \mathrm{U}$ age of $238.6 \pm 2.6$ $\mathrm{Ma}(\mathrm{n}=8)$ with a $\mathrm{Th} / \mathrm{U}$ value of 0.50 , and inherited cores that yielded a concordant ${ }^{206} \mathrm{~Pb} /{ }^{238} \mathrm{U}$ age of $267.8 \pm 4.2 \mathrm{Ma}(\mathrm{n}=5)$ with a $\mathrm{Th} / \mathrm{U}$ value of 0.54 . 
Table 1. Summary of LA-ICPMS U-Pb zircon ages

\begin{tabular}{|c|c|c|c|c|c|}
\hline \multirow{2}{*}{ Location \# } & \multirow{2}{*}{ Sample No. } & \multirow{2}{*}{ Rock name } & \multicolumn{2}{|c|}{ Zircon U-Pb age (Ma) } & \multirow{2}{*}{$\begin{array}{l}\text { Latitude }\left({ }^{0} \mathrm{~N}\right), \\
\text { Longitude }\left({ }^{0} \mathrm{E}\right)\end{array}$} \\
\hline & & & $\begin{array}{l}\text { Magmatic } \\
\text { age }\end{array}$ & Inherited zircon age & \\
\hline \multicolumn{6}{|l|}{ Baidrag area } \\
\hline 15082205 & $15082205 \mathrm{~A}$ & Bt granite & $532.5 \pm 3.7$ & $\begin{array}{c}943 \pm 28,1668 \pm 53 \\
1900 \pm 51\end{array}$ & $\begin{array}{l}46.3094 \\
99.5612\end{array}$ \\
\hline 11083105 & 11083105 & Ms granite & $554.0 \pm 26$ & $705 \pm 19,883 \pm 22$ & $\begin{array}{l}46.3231 \\
99.9721\end{array}$ \\
\hline 13082407 & 13082407 & Ms granite & $543.0 \pm 22$ & $\begin{array}{c}858 \pm 26,1083 \pm 30 \\
1185 \pm 32\end{array}$ & $\begin{array}{c}46.1709 \\
100.0819\end{array}$ \\
\hline 13082408 & $13082408 \mathrm{I}$ & Leucogranite & $564.0 \pm 16$ & $931 \pm 30$ & $\begin{array}{c}46.1503 \\
100.2018\end{array}$ \\
\hline 13082408 & $13082408 \mathrm{~J}$ & Bt granite & $550.8 \pm 7$ & $1138 \pm 32$ & $\begin{array}{c}46.1503 \\
100.2018\end{array}$ \\
\hline 13082410 & $13082410 \mathrm{C}$ & Bt granite & $552.2 \pm 3.8$ & $1958 \pm 49$ & $\begin{array}{c}46.1438 \\
100.2506\end{array}$ \\
\hline 15082102 & 15082102 & $\mathrm{Bt}-\mathrm{Hbl}$ granite & $532.0 \pm 5.2$ & $769 \pm 22$ & $\begin{array}{c}46.1611 \\
100.3045\end{array}$ \\
\hline \multicolumn{6}{|l|}{ Khangai area } \\
\hline 15082302 & $15082302 \mathrm{~A}$ & $\mathrm{Bt}-\mathrm{Hbl}$ granodiorite & $262.4 \pm 1.8$ & - & $\begin{array}{c}46.8059 \\
100.0048\end{array}$ \\
\hline 11083003 & $11083003 \mathrm{~A}$ & $\mathrm{Bt}-\mathrm{Hbl}$ granodiorite & $254.3 \pm 3.8$ & - & $\begin{array}{c}46.8067 \\
100.0045\end{array}$ \\
\hline 11083002 & $11083002 \mathrm{~A}$ & Bt granite & $569.6 \pm 3.9$ & - & $\begin{array}{l}46.8116 \\
99.9428\end{array}$ \\
\hline 11083001 & $11083001 \mathrm{~A} 9$ & Bt granite & $263.4 \pm 5.7$ & - & $\begin{array}{l}46.8054 \\
99.8750\end{array}$ \\
\hline 110829T01 & 110829T01F1 & Granite & $265.5 \pm 3.0$ & - & $\begin{array}{l}46.8038 \\
99.8705\end{array}$ \\
\hline 15082401 & $15082401 \mathrm{~A}$ & $\mathrm{Bt}-\mathrm{Hbl}$ granodiorite & $259.9 \pm 2.0$ & - & $\begin{array}{l}47.2386 \\
99.6607\end{array}$ \\
\hline 15082401 & $15082401 \mathrm{C}$ & $\mathrm{MME}$ in $\mathrm{Bt}-\mathrm{Hbl}$ granodiorite & $257.5 \pm 2.7$ & - & $\begin{array}{l}47.2386 \\
99.6607 \\
\end{array}$ \\
\hline 11082803 & $11082803 \mathrm{~A}$ & $\mathrm{Bt}-\mathrm{Hbl}$ granodiorite & $262.3 \pm 2.0$ & - & $\begin{array}{c}47.7224 \\
100.2071\end{array}$ \\
\hline 15082305 & $15082305 \mathrm{D} 2$ & MME in $\mathrm{Bt}-\mathrm{Hbl}$ granodiorite & $262.1 \pm 3.7$ & - & $\begin{array}{l}46.9369 \\
99.8725\end{array}$ \\
\hline 15082801 & $15082801 \mathrm{~A}$ & $\mathrm{Bt}-\mathrm{Hbl}$ granodiorite & $249.3 \pm 2.4$ & - & $\begin{array}{c}47.4170 \\
101.9744\end{array}$ \\
\hline 15082002 & $15082002 \mathrm{~A}$ & Bt granite & $248.7 \pm 3.1$ & - & $\begin{array}{c}45.8293 \\
101.7545\end{array}$ \\
\hline 15082710 & 15082710 & Pegmatitic granite & $237.8 \pm 2.2$ & - & $\begin{array}{c}47.5017 \\
101.4175 \\
\end{array}$ \\
\hline 15082302 & $15082302 \mathrm{D}$ & Granitic dike & $238.6 \pm 2.6$ & $267.8 \pm 4.2$ & $\begin{array}{c}46.8059 \\
100.0048\end{array}$ \\
\hline
\end{tabular}


Whole-rock geochemistry

The whole-rock geochemical compositions of a total of 65 samples were determined during this study.

564-532 Ma Baidrag granitoids. The biotitehornblende and biotite-muscovite granites in the Baidrag area contain $61.56-73.85$ wt. $\% \mathrm{SiO}_{2}$ and 14.66-18.08 wt. $\% \mathrm{Al}_{2} \mathrm{O}_{3}$. They have total iron expressed as $\mathrm{TFe}_{2} \mathrm{O}_{3}$ concentrations of 0.97 -5.11 wt. $\%$ and low concentrations of $\mathrm{MgO}$ (0.24-1.94 wt.\%) and $\mathrm{CaO}(0.61-4.32$ wt.\%). They have high total alkali contents $\left(\mathrm{K}_{2} \mathrm{O}+\right.$ $\mathrm{Na}_{2} \mathrm{O}=7.0-9.1$ wt. $\%$ ) and $\mathrm{K}_{2} \mathrm{O}$ concentrations of 2.68-4.55 wt.\%, indicating they are high-K and calc-alkaline.

The biotite-muscovite granites are enriched in the large-ion lithophile elements (LILE; Ba, Sr, and $\mathrm{Th}$ ), but are depleted in $\mathrm{Nb}$, Ta, $\mathrm{P}$, and $\mathrm{Ti}$, yielding primitive-mantle-normalized multielement patterns that are similar to those of the continental crust (Taylor and McLennan, 1985; Fig. 5). They have chondrite-normalized REE patterns that have moderate light REE/heavy REE (LREE/HREE) ratios $\left((\mathrm{La} / \mathrm{Yb})_{\mathrm{N}}=13.96-\right.$ 46.16, where $\mathrm{N}$ indicates chondrite normalization) with variable $\mathrm{Eu}$ anomalies $(\mathrm{Eu} /$ $\underline{\mathrm{Eu}}^{*}=0.76-1.63, \mathrm{Eu}$ anomalies $\left(\mathrm{Eu} / \mathrm{Eu}^{*}\right)$ have been calculated as $\mathrm{Eu} / \mathrm{Eu}^{*}=(\mathrm{Eu})_{\mathrm{cn}} /[(\mathrm{Sm})$ cn X $\left.(\mathrm{Gd})_{\mathrm{cn}}\right]^{0.5}$ from Sun and McDonough (1989); Fig. 5). The biotite-hornblende granites that contain MME have LILE ( $\mathrm{Rb}, \mathrm{Ba}$, and $\mathrm{Sr}$ ) enriched primitive-mantle-normalized multielement patterns (Fig. 5). Their chondritenormalized REE patterns are characterized by low LREE/HREE ratios $\left((\mathrm{La} / \mathrm{Yb})_{\mathrm{N}}=4.82-\right.$ 11.26) ) and negative $\mathrm{Eu}$ anomalies $\left(\mathrm{Eu} / \mathrm{Eu}^{*}=\right.$ 0.70-0.75; Fig. 5). The biotite-hornblende granites without MME are geochemically similar to the biotite-muscovite granites, but are depleted in the HREE relative to these granites, indicating these two sets of granites probably have different sources. The majority of these samples plot within the volcanic arc field in the tectonic discrimination diagrams shown in Fig. 6a-d.

269-248 Ma Khangai granitoids. The 269-248 Ma Khangai biotite-hornblende granodiorite and biotite granite units are geochemically variable and contain $54.44-75.93$ wt. $\% \mathrm{SiO}_{2}$ and moderate to slightly elevated concentrations of $\mathrm{Al}_{2} \mathrm{O}_{3}$ (12.81-19.62 wt.\%). They have $\mathrm{TFe}_{2} \mathrm{O}_{3}$ concentrations of $0.55-7.88$ wt. $\%$ and contain 0.06-3.18 wt. $\% \mathrm{MgO}$ and $0.20-5.46$ wt. $\% \mathrm{CaO}$ (Fig. 7). These units have total alkali $\left(\mathrm{K}_{2} \mathrm{O}+\right.$ $\mathrm{Na}_{2} \mathrm{O}$ ) values of $6.59-9.84$ wt. $\%$ and contain 2.46-6.35 wt. $\% \mathrm{~K}_{2} \mathrm{O}$, indicating they have high$\mathrm{K}$ calc-alkaline to shoshonitic compositions. The biotite-hornblende granodiorites are enriched in $\mathrm{Rb}, \mathrm{U}$, and $\mathrm{Th}$, but are depleted in the high-field -strength elements (HFSE; $\mathrm{Nb}, \mathrm{Ta}$, and $\mathrm{Ti}$ ) relative to the continental crust (Taylor and McLennan, 1985; Fig. 8). They have chondritenormalized REE patterns that are characterized by moderate LREE/HREE ratios $\left((\mathrm{La} / \mathrm{Yb})_{\mathrm{N}}=\right.$ 4.51-33.03) with variable Eu anomalies (Eu/Eu* $=0.64-1.42$; Fig. 8). The biotite granites have primitive-mantle-normalized multi-element patterns that are relatively enriched in $\mathrm{Rb}, \mathrm{Th}$, $\mathrm{U}$, and $\mathrm{Pb}$, but are depleted in $\mathrm{Nb}, \mathrm{Ta}, \mathrm{Sr}, \mathrm{Eu}, \mathrm{P}$, and Ti (Fig. 8). Their chondrite-normalized REE patterns have relatively high LREE/HREE ratios $\left.\left((\mathrm{La} / \mathrm{Yb})_{\mathrm{N}}=3.15-73.59\right)\right)$ and negative $\mathrm{Eu}$ anomalies $\left(\mathrm{Eu} / \mathrm{Eu}^{*}=0.18-0.96\right.$; Fig. 8), indicating these biotite granites are more differentiated than the other Khangai granitoids.

The biotite-hornblende granodiorites are classified as unfractionated granites, whereas the biotite granites are classified as fractionated granites in a $\left(\mathrm{TFe}_{2} \mathrm{O}_{3} / \mathrm{MgO}\right)$ vs. $(\mathrm{Zr}+\mathrm{Nb}+\mathrm{Y}+$ Ce) discrimination diagram (Fig. 9a). In addition, the biotite-hornblende granodiorites are classified as volcanic arc granites and some of the biotite granites are classified as collisionrelated granites in a $\mathrm{Rb}$ vs. $(\mathrm{Y}+\mathrm{Nb})$ tectonic discrimination diagram (Fig. 9b), although the latter may reflect the effect of fractionation. The biotite-hornblende granodiorites are also classified as volcanic arc and late/postcollisional granites in a ternary $\mathrm{Hf}-\mathrm{Rb}-\mathrm{Ta}$ tectonic discrimination diagram (Fig. 9c).

238-237 Ma Khangai granitoids. The 238-237 Ma Khangai pegmatitic granite and granitic dike units have high concentrations of $\mathrm{SiO}_{2}$ (71.4678.32 wt. $\%$ ) and moderate concentrations of $\mathrm{Al}_{2} \mathrm{O}_{3}$ (11.78 to 14.63 wt.\%). They also contain 

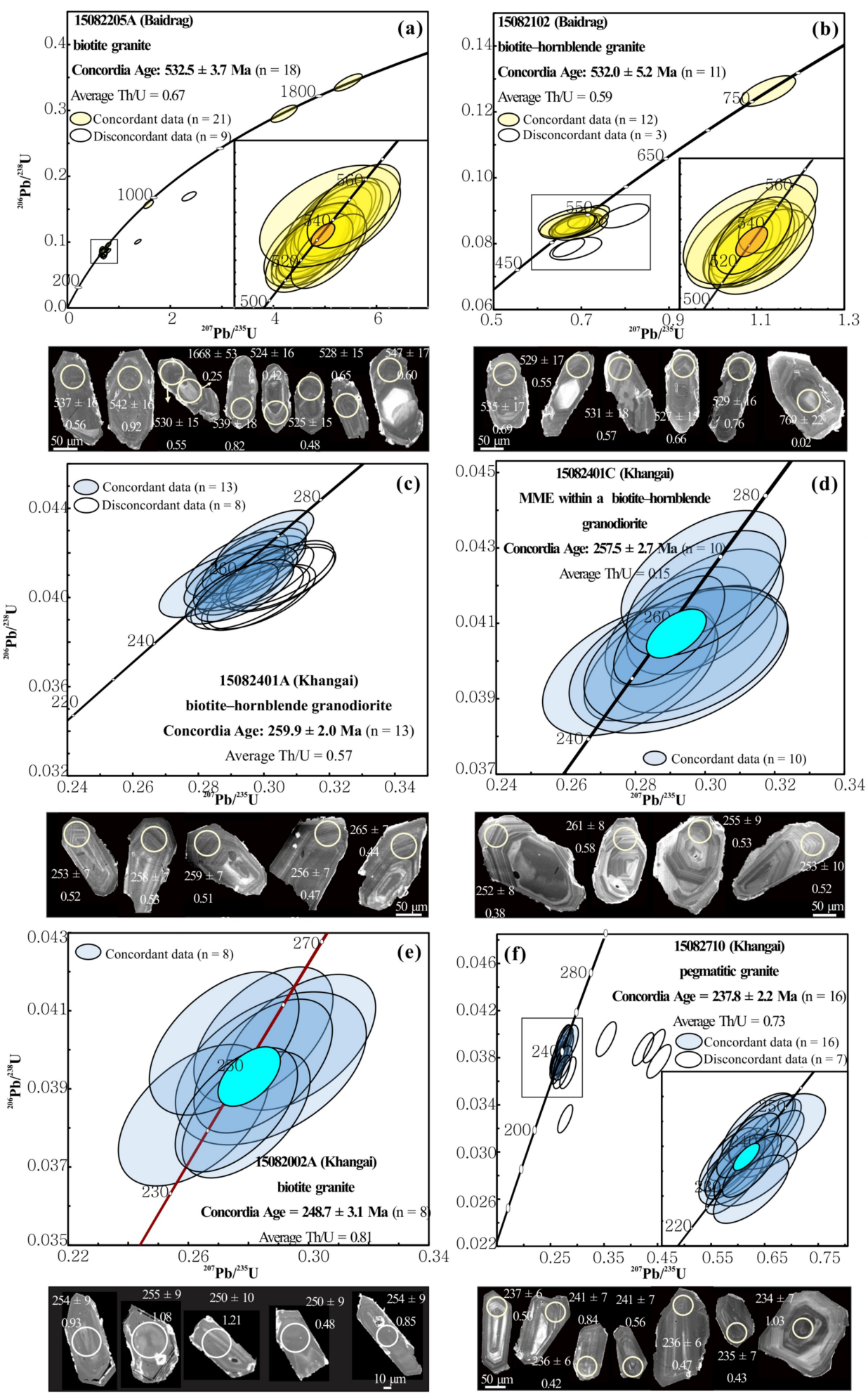

Fig. 4. Zircon $\mathrm{U}-\mathrm{Pb}$ concordia diagrams, cathodoluminescene $(\mathrm{CL})$ images with analysis spots for granitoids within the Baidrag and Khangai areas. The concordant and discordant data are shown as colored and colorless ellipses, respectively. The inset figures are enlarged views of the areas enclosed in black boxes. (a) Biotite granite (sample 15082205A), (b) Biotite-hornblende granite (sample 15082102), (c) Biotite-hornblende granodiorite (sample 15082401A), (d) A MME within a biotite- hornblende granodiorite (sample 15082401C), (e) Biotite granite (sample 15082002A), (f) Pegmatitic granite (sample 15082710). 

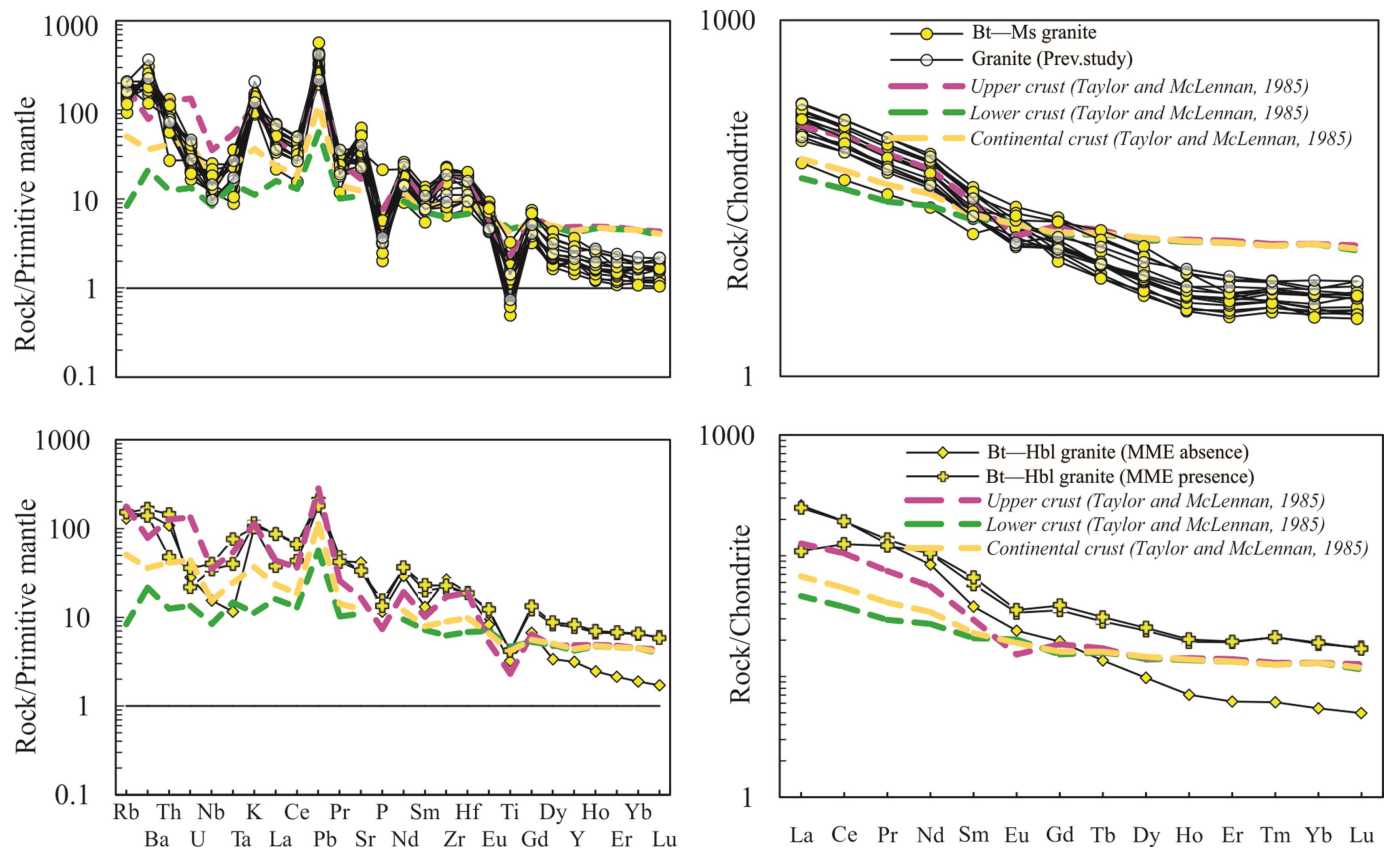

Fig. 5. Primitive-mantle-normalized multi-element and chondrite-normalized REE patterns for granitoids samples from the Baidrag area. These diagrams are normalized to the primitive mantle and chondrite compositions of Sun and McDonough (1989), and include data from Buchan et al. (2002), Jahn et al. (2004), and Zhang et al. (2015).
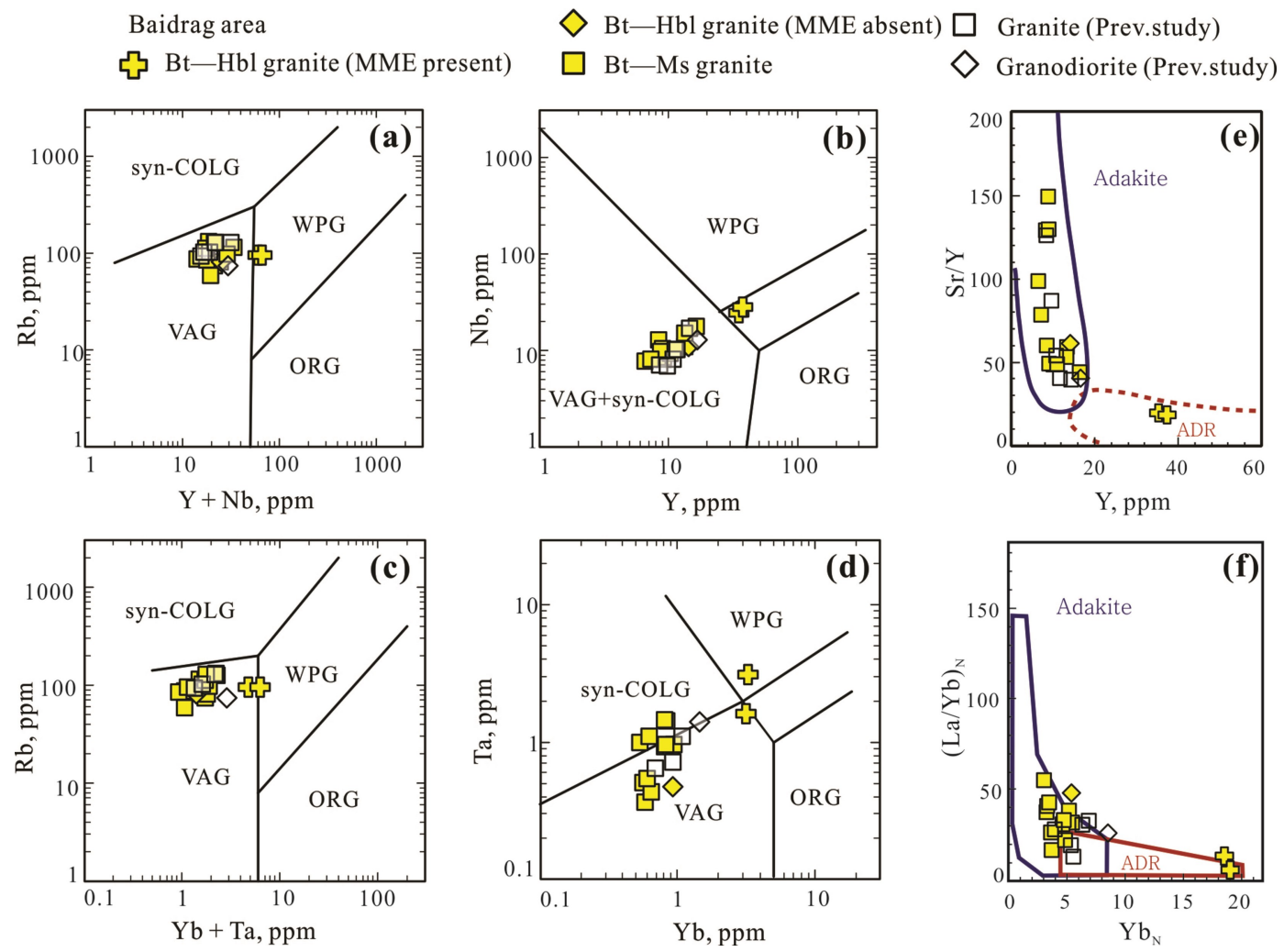

Fig. 6. Diagrams showing granitoids of the Baidrag area plotted on tectonic discrimination diagrams. (a) $\mathrm{Rb}$ vs. $\mathrm{Y}+\mathrm{Nb}$, (b) $\mathrm{Nb}$ vs. $\mathrm{Y}$, (c) $\mathrm{Rb}$ vs. $\mathrm{Yb}+\mathrm{Ta}$, and (d) Ta vs. Yb. Abbreviations are as follows: VAG $=$ volcanic arc granite, $\mathrm{COLG}=$ collisional granite, $\mathrm{WPG}=$ within plate granite, and $\mathrm{ORG}=$ ocean ridge granite; after Pearce et al. (1984). (e-f) Adakite vs. andesite-dacite-rhyolite (ADR) discrimination diagrams of Drummond and Defant (1990) with boundaries of Richards and Kerrich (2007). These diagrams also include previously published data from Buchan et al. (2002), Jahn et al. (2004), and Zhang et al. (2015). 
0.92-2.12 wt.\% $\quad \mathrm{TFe}_{2} \mathrm{O}_{3}$ and very low concentrations of $\mathrm{MgO}(0.04-0.81$ wt.\%) and $\mathrm{CaO}$ (0.25 to 1.45 wt.\%; Fig. 7). Two of the granitic dikes in this area also have high concentrations of $\mathrm{SiO}_{2}(72.53-72.70 \mathrm{wt} . \%)$ and $\mathrm{Al}_{2} \mathrm{O}_{3} \quad(15.28-15.40 \quad$ wt.\%), but low concentrations of $\mathrm{TFe}_{2} \mathrm{O}_{3} \quad(1.52-1.54$ wt.\%), $\mathrm{MgO}$ (0.39 wt.\%), and $\mathrm{CaO}$ (1.35-1.37 wt.\%; Fig. 7). The pegmatitic granite and granitic dike units in this area have total alkali $\left(\mathrm{K}_{2} \mathrm{O}+\mathrm{Na}_{2} \mathrm{O}\right)$ concentrations of 7.02-10.04 wt. \% and contain 4.12-6.73 wt. $\% \mathrm{~K}_{2} \mathrm{O}$, indicating they have high$\mathrm{K}$ calc-alkaline to shoshonitic affinities. These pegmatitic granites have primitive-mantlenormalized multi-element patterns that are depleted in the HREE and are characterized by negative $\mathrm{Ba}, \mathrm{Sr}, \mathrm{P}, \mathrm{Eu}, \mathrm{Ti}, \mathrm{Nb}$, and $\mathrm{Ta}$, and positive $\mathrm{Rb}, \mathrm{Pb}$, Th, and $\mathrm{U}$ anomalies (Fig. 8). Their chondrite-normalized REE patterns have variable LREE/HREE ratios $\left((\mathrm{La} / \mathrm{Yb})_{\mathrm{N}}=0.23-\right.$ $18.90))$ with marked negative Eu anomalies $(\mathrm{Eu} /$ $\mathrm{Eu}^{*}=0.02-0.53$; Fig. 8). The two granitic dike samples have primitive-mantle-normalized multi -element patterns that are depleted in $\mathrm{Nb}, \mathrm{Ta}, \mathrm{Sr}$, $\mathrm{P}$, and $\mathrm{Ti}$, and are enriched in $\mathrm{Rb}, \mathrm{Th}, \mathrm{U}$, and $\mathrm{Pb}$ (Fig. 8). Their chondrite-normalized REE patterns have high LREE/HREE ratios $((\mathrm{La} / \mathrm{Yb})$ $\mathrm{N}=29.57-60.33)$ ) with negative $\mathrm{Eu}$ anomalies $\left(\mathrm{Eu} / \mathrm{Eu}^{*}=0.66-0.83\right.$; Fig. 8). Plotting the pegmatitic granites and granitic dikes in classification diagrams indicates they are fractionated granites with high $\mathrm{TFe}_{2} \mathrm{O}_{3} / \mathrm{MgO}$ ratios (2.63-25.95; Fig. 10a), high Y contents, and high $10000 * \mathrm{Ga} / \mathrm{Al}$ ratio (>2.4; Fig. 10b).

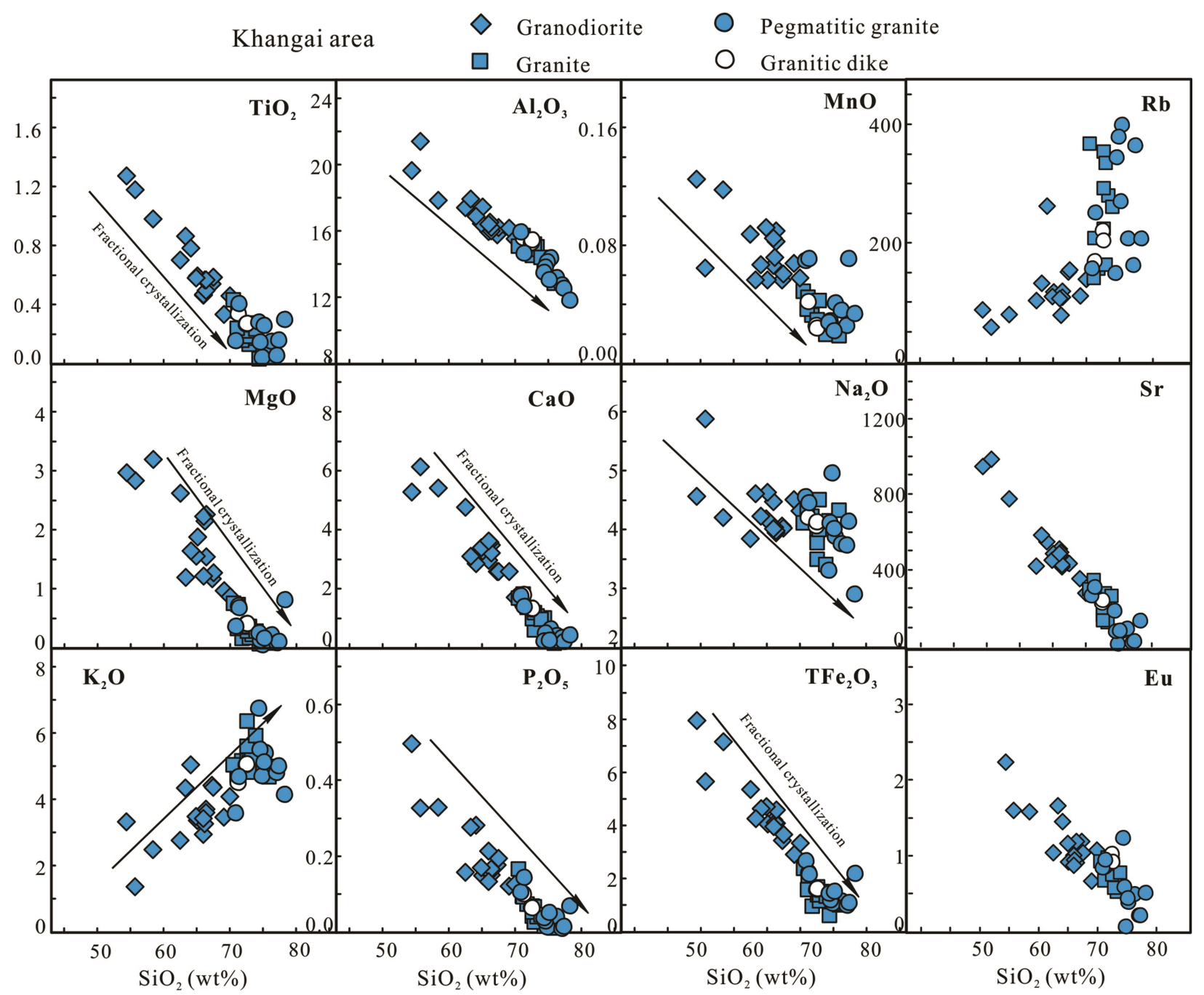

Fig. 7. Harker diagrams showing variations in the composition of granitoids from the Khangai area. Major oxides unit is expressed by weight percent and trace elements unit is expressed by part per million (ppm). 
The majority of these samples are classified as post-collisional granites in both ternary $\mathrm{Y}-\mathrm{Nb}-$ $\mathrm{Zr}$ (Fig. 10c) and $\mathrm{Rb}$ vs. ( $\mathrm{Y}+\mathrm{Nb})$ discrimination diagrams, with the exception of the two granitic dikes in the latter diagram (Fig. 10d). The majority of these samples are also classified as late or post-collisional granites in a ternary $\mathrm{Hf}-\mathrm{Rb}$-Ta diagram (Fig.10e).

\section{DISCUSSION}

The new zircon $\mathrm{U}-\mathrm{Pb}$ dates obtained during this study indicate that the Khangai region records three stages of magmatism at 564-532, 269248, and 238-237 Ma. The 564-532 Ma magmatic event within the Baidrag area is thought to be related to subduction and
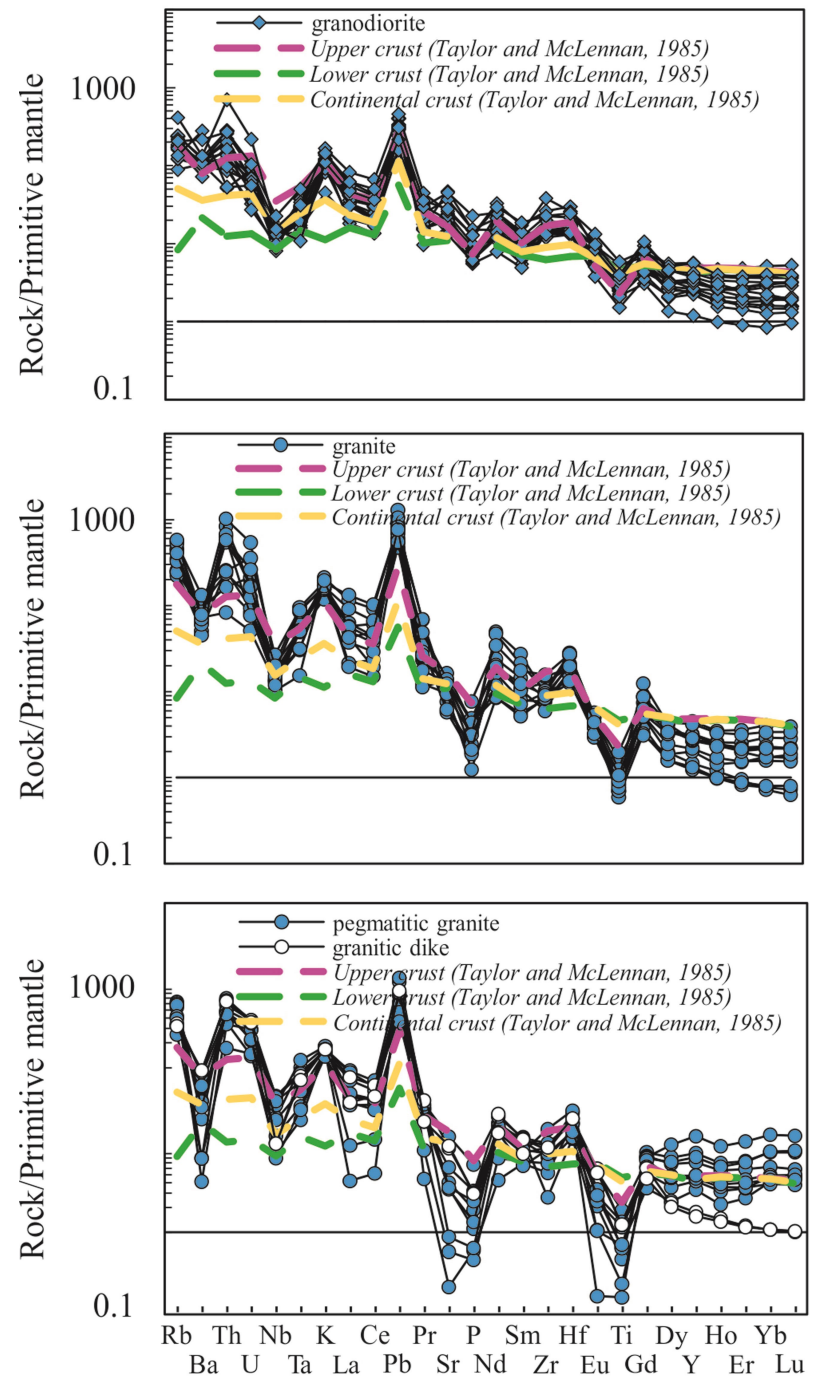

accretion processes (Demoux et al., 2009), whereas the Permian-Triassic (269-248 and 238 $-237 \mathrm{Ma}$ ) magmatic events are thought to be related to the formation of the Khangai-Khentii -Daurian zone within the MOFB (Zorin, 1999).

\section{4-532 Ma magmatic event}

Zircons from the Baidrag granitic rocks are euhedral, elongate, and have regular oscillatory zoning visible during CL imaging, suggesting a magmatic origin (Corfu et al., 2003), which is consistent with their high $\mathrm{Th} / \mathrm{U}$ ratios $(0.59$ 0.94). The zircon $\mathrm{U}-\mathrm{Pb}$ dating of seven granitic samples from different plutons in the Baidrag area indicates that these intrusions were emplaced at 564-532 Ma, consistent with
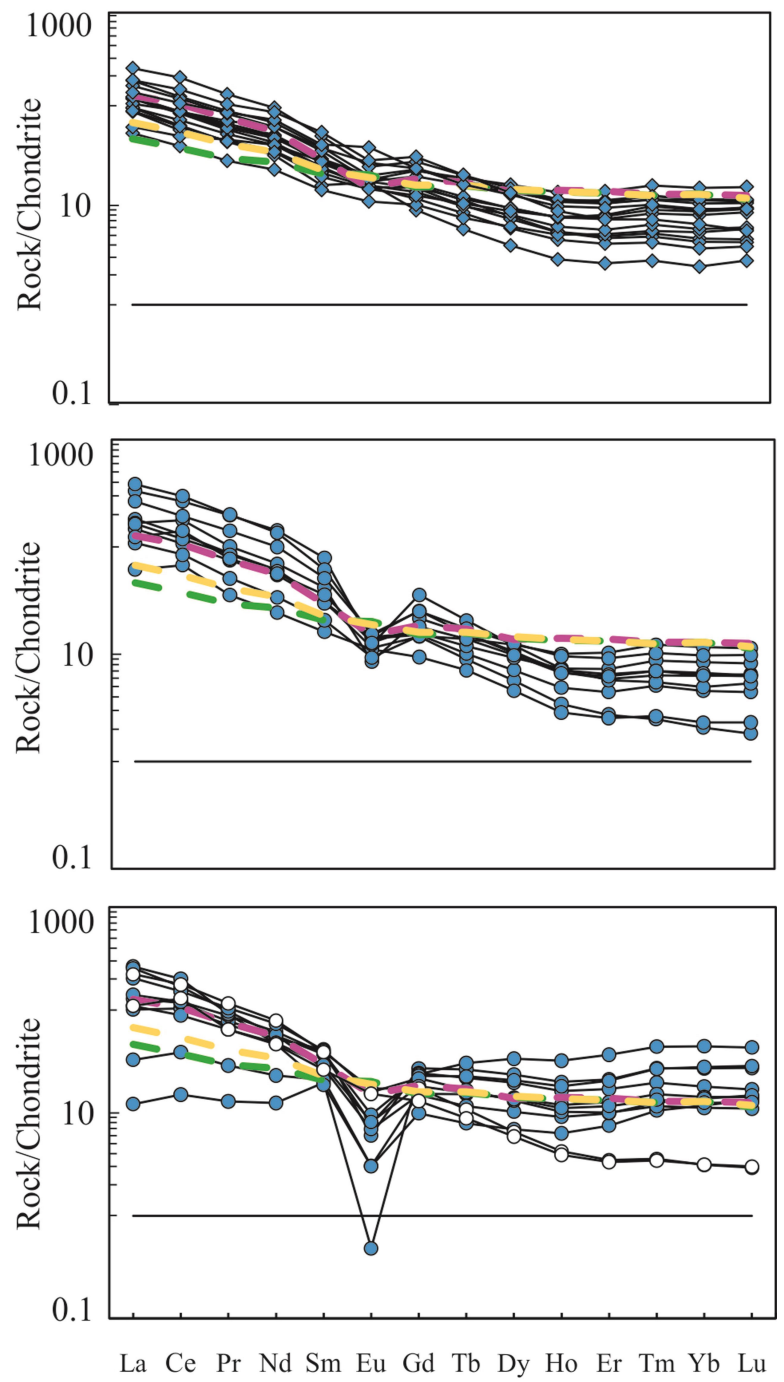

Fig. 8. Primitive-mantle-normalized multi-element and chondrite-normalized REE diagrams showing variations in the compositions of granitoids from the Khangai area. Normalizing values are from Sun and McDonough (1989). 
recently reported ages for 547-546 Ma granites and mafic enclaves within the Ulaan-Uul batholith in this region (Zhang et al., 2015). These samples also contain inherited entire zircons and zircon cores that yield ca. 700, ca. 800 , ca. 900 , ca. 1100 , ca. 1200 , ca. 1700 , and ca. $1900 \mathrm{Ma}$ ages.

\section{Petrogenesis of granitic rocks in the Baidrag area}

The biotite-muscovite granites from the Baidrag area have adakitic affinities as evidenced by their plotting within the adakite field in a $\mathrm{Sr} / \mathrm{Y}$ vs. Y diagram (Fig. 6e-f), whereas the biotitehornblende granites from this area plot in the typical arc magma field of this diagram. As such, the rest of the discussion of these samples focuses on the characteristics of the adakitic and non-adakitic suites. The adakitic samples are high-K and calc-alkaline, are very depleted in the HREE $(\mathrm{Yb}=0.53-0.94 \mathrm{ppm} ; \mathrm{Y}=6.6-16.4$ ppm), have small to no Eu anomalies (Fig. 5), and have high $\mathrm{Sr} / \mathrm{Y}$ ratios (Fig. 6e-f), all of which are similar to the characteristics of typical adakites. The HREE- and Y-depleted nature of adakites suggests they are derived from a magma source containing garnet and/or hornblende are as a residual phases (Defant and Drummond, 1990; Drummond et al., 1996; Martin, 1999). The absence of significant $\mathrm{Eu}$ anomalies and the high Sr concentrations of the Baidrag granites also suggest that they were derived from plagioclase free mafic source rocks in very thick crustal section (Kay and Mahlburg-Kay, 1991). Adakitic magmas can be generated by the partial melting of subducted oceanic slab material or the fractional crystallization of basaltic magmas (Defant and Drummond, 1990; Castillo, 2012). It is likely that the melting of oceanic slab material, including basalts and overlying metasediments, beneath the Baidrag Craton (Adachi et al., 2012a) generated the adakitic magmas that were emplaced in this area. Previous research (Jahn et al., 2004) determined that the biotite-muscovite granites have ${ }^{87} \mathrm{Sr} /{ }^{86} \mathrm{Sr}$ ratios $\left(\mathrm{I}_{\mathrm{Sr}}\right)$ of $\sim 0.7078$ and an $\varepsilon_{\mathrm{Nd}}(\mathrm{T})$ value of -7.0 , suggesting that metasediments were involved in the oceanic basalt melting-dominated petrogenesis of these granites. This is consistent with the presence of detrital zircons within these samples. The nonadakitic rocks within the Baidrag area are classified as normal volcanic arc granites (Fig. 6e-f), suggesting that the two sets of granites in this area were derived from separate sources, with adakites derived from the melting of oceanic slab material (including basalts and metasediments) and non-adakites derived from the contemporaneous melting of juvenile crustal material.

\section{Tectonic setting of the 564-532 Ma Baidrag granitoid magmatism}

The Lake zone within the eastern margin of the Baidrag area contains eclogites that yield an ${ }^{40} \mathrm{Ar} /{ }^{39} \mathrm{Ar}$ cooling age of ca. $540 \mathrm{Ma}$ (Štípská et al., 2010), indicating that these units formed same period with the granitic magmatism in this area. The geochemistry of the adakitic rocks is indicative of formation within a volcanic arc
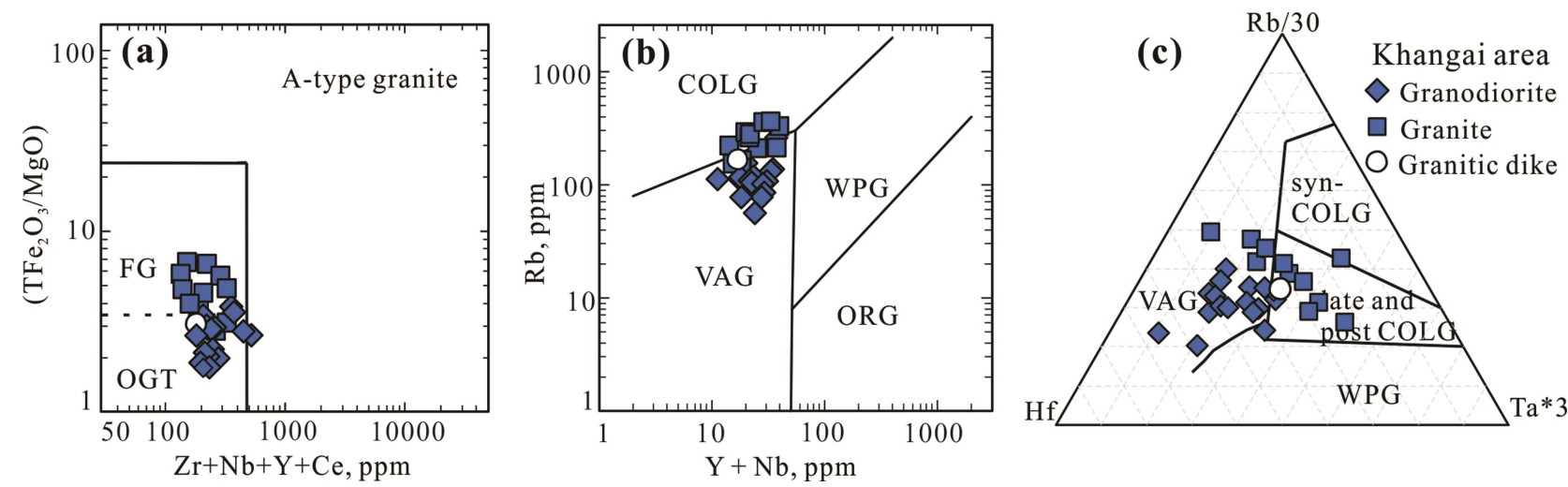

Fig. 9. Diagrams showing granitic rocks from the Khangai area plotted on tectonic discrimination diagrams. (a) $\mathrm{TFe}_{2} \mathrm{O}_{3} / \mathrm{MgO}$ vs. $(\mathrm{Zr}+\mathrm{Nb}+\mathrm{Y}+\mathrm{Ce})$ after Whalen et al. (1987). (b) $\mathrm{Rb}$ vs. $(\mathrm{Y}+\mathrm{Nb})$ after Pearce et al. (1984). (c) Ternary Hf vs. Rb/30 vs. Ta*3 diagram after Harris et al. (1986). Abbreviations are as in Fig. 6 with OGT = unfractionated granite and $\mathrm{FG}=$ fractionated granite. 

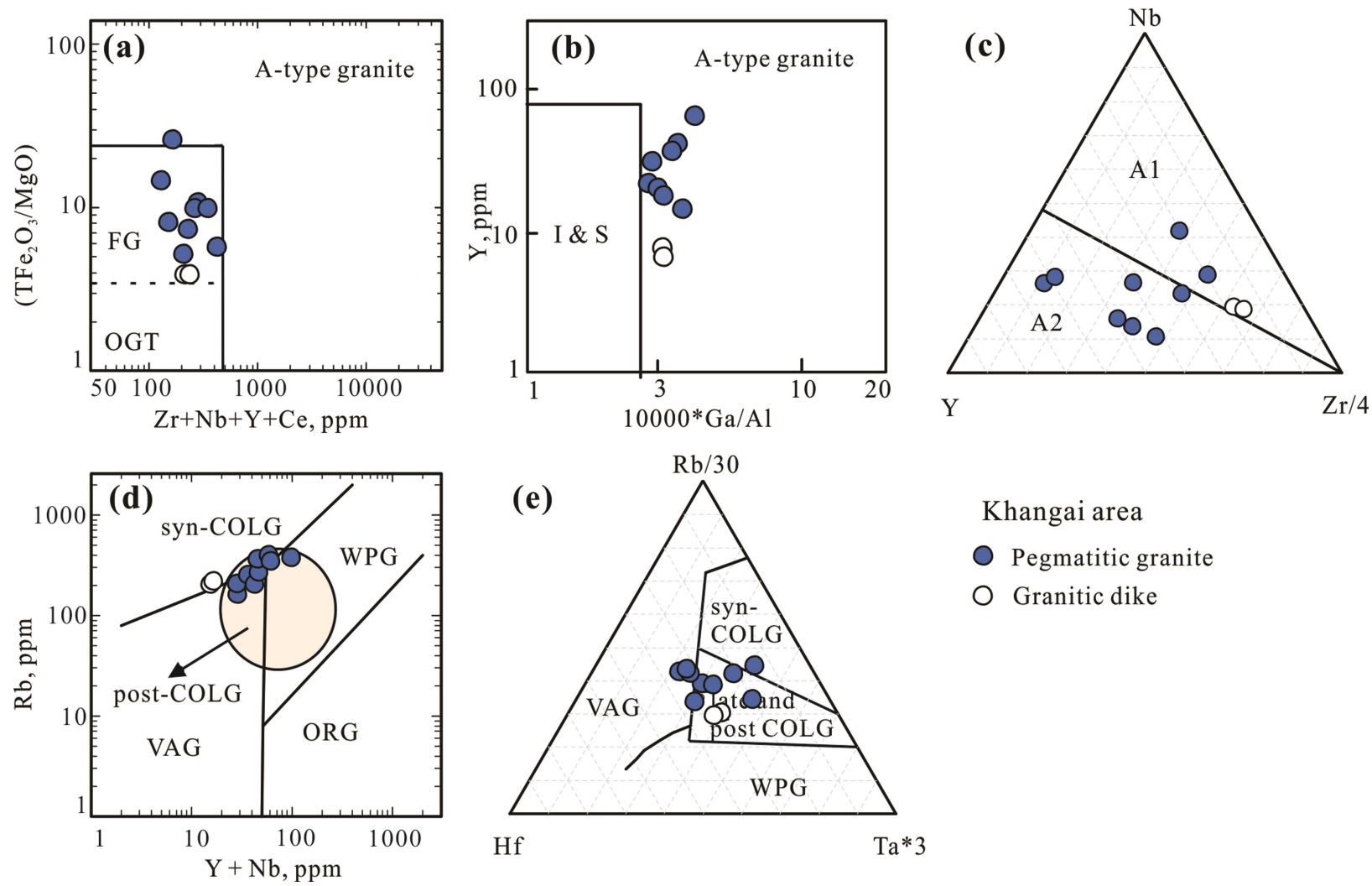

Fig. 10. Diagrams showing granitic rocks from the Khangai area plotted on tectonic discrimination diagrams. (a) $\mathrm{TFe}_{2} \mathrm{O}_{3} / \mathrm{MgO}$ vs. $(\mathrm{Zr}+\mathrm{Nb}+\mathrm{Y}+\mathrm{Ce}$ ) diagram after Whalen et al. (1987). (b) $\mathrm{Y}$ vs. $10000 * \mathrm{Ga} / \mathrm{Al}$ diagram discriminating between I-, S-, and A-type granites after Whalen et al. (1987). (c) Ternary Y vs. Nb vs. Zr/4 diagram after Eby (1992). (d) Rb vs. $(\mathrm{Y}+\mathrm{Nb}$ ) diagram after Pearce et al. (1984). (e) Ternary Hf vs. Rb/30 vs. Ta*3 diagram after Harris et al. (1986). Abbreviations are as in Figs 6 and 9 with A1 = intraplate rifting and A2= post-collisional, I-igneous, S-sedimentary.

environment (Fig. 6a-d), consistent with the presence of negative $\mathrm{Nb}$, $\mathrm{Ta}$, and $\mathrm{Ti}$ anomalies in the primitive-mantle-normalized multielement patterns for these samples (Fig. 5). This indicates that the slab-derived adakitic magmas that were emplaced in this area did not provide sufficient heat to drive the subduction-related partial melting of the lower crust in this region. The fact that the adakitic and non-adakitic Itype magmatism in the Baidrag area was contemporaneous suggests that these granitoids formed in a continental arc-type environment.

\section{9-248 and 238-237 Ma magmatic events}

The zircons from the biotite-hornblende granodiorites, MME, and biotite granites in this region are euhedral, elongate, have regular oscillatory zoning visible in CL imaging, and are free of inherited cores, suggesting they have a magmatic origin (Corfu et al., 2003). The zircons from the biotite-hornblende granodiorites and associated MME yield $\mathrm{U}-\mathrm{Pb}$ ages from 263 to $249 \mathrm{Ma}$, whereas the zircons from the biotite granites yield $\mathrm{U}-\mathrm{Pb}$ ages from 269 to $248 \mathrm{Ma}$, suggesting that all of these units formed contemporaneously. Most of the zircons from the pegmatitic granites have oscillatory zoning visible in CL imaging and also lack inherited cores, but some are unzoned and appear dark during CL imaging, suggesting they contain high concentrations of Uranium. However, all of these characteristics are also indicative of a magmatic origin. In addition, zircons from the granitic dike contain inherited cores surrounded by oscillatory zoned overgrowths that suggest the former were generated during a thermal event that occurred before the crystallization of the latter (Corfu et al., 2003). The zircons from the pegmatitic granites yield a $\mathrm{U}-\mathrm{Pb}$ age of $237 \mathrm{Ma}$ that is similar to the $238 \mathrm{Ma}$ age obtained for zircons from the granitic dike, suggesting that both 
magmatic units formed contemporaneously. In addition, the zircons within the granitic dike contain inherited cores that yield a U-Pb age of $267 \mathrm{Ma}$, consistent with the timing of formation of the hosting granitoids. Here, we provide regional context for the 269-248 and 238-237 $\mathrm{Ma}$ granitoids within the Khangai area by comparing the timing of this magmatism to the timing of other magmatic events within the MOFB. A 269-248 Ma magmatic event has also been identified within the Erguna massif of northeastern China (Tang et al., 2015), whereas post-orogenic granitoids from the Khentii area yielded younger ages of 208-205 Ma (Khishigsuren et al., 2012). This suggests that the Khangai granitoids formed within the western margin of the Khangai-KhentiiDaurian zone, which was a constituent part of the MOFB (Zorin, 1999; Donskaya et al., 2012; Tang et al., 2015).

\section{Petrogenesis of granitoids in the Khangai area} 269-248 Ma granitoids. Both the 269-248 Ma biotite-hornblende granodiorites that contain MME and the medium- to fine-grained biotite granites in this area are free of muscovite and $\mathrm{Al}$ -rich minerals such as garnet, aluminosilicates, and cordierite. The presence of hornblende and the absence of Al-rich minerals suggest that these samples probably have I-type affinity, consistent with their aluminum saturation index (ASI) values, all of which are $>1.1$ (Chappell and White 2001). Both the biotite-hornblende granodiorites and biotite granites have $\mathrm{SiO}_{2}$ contents that range from 54.44 to $75.93 \mathrm{wt} . \%$ and both define a single trend on Harker diagrams that likely reflects fractional crystallization processes (Fig. 7). The concentrations of some of the LILE within these samples (e.g., Sr, Eu, and Rb) also define linear trends on Harker diagrams (Fig. 7), suggesting that the evolved biotite granites were derived from the more primitive biotite-hornblende granodiorites. The biotite granites also have high $\mathrm{TFe}_{2} \mathrm{O}_{3} / \mathrm{MgO}$ values that are indicative of fractionated granites, whereas the lower values of the biotite-hornblende granodiorites are indicative of unfractionated granites (Fig. 11a). Plotting these samples on a hornblende, biotite, and plagioclase vector diagram indicates that these two suites of granitoids can be linked by the fractionation of plagioclase and hornblende (Fig. 11b). In addition, the primitive-mantlenormalized multi-element patterns of the biotite -hornblende granodiorites are characterized by positive $\mathrm{Ba}$ and $\mathrm{Sr}$ and negative $\mathrm{Nb}, \mathrm{Ta}$, and $\mathrm{Ti}$ anomalies. These anomalies suggest that these granodiorites formed from magmas derived from a source containing residual amphibole and/or rutile (Martin et al. 2005). The relatively
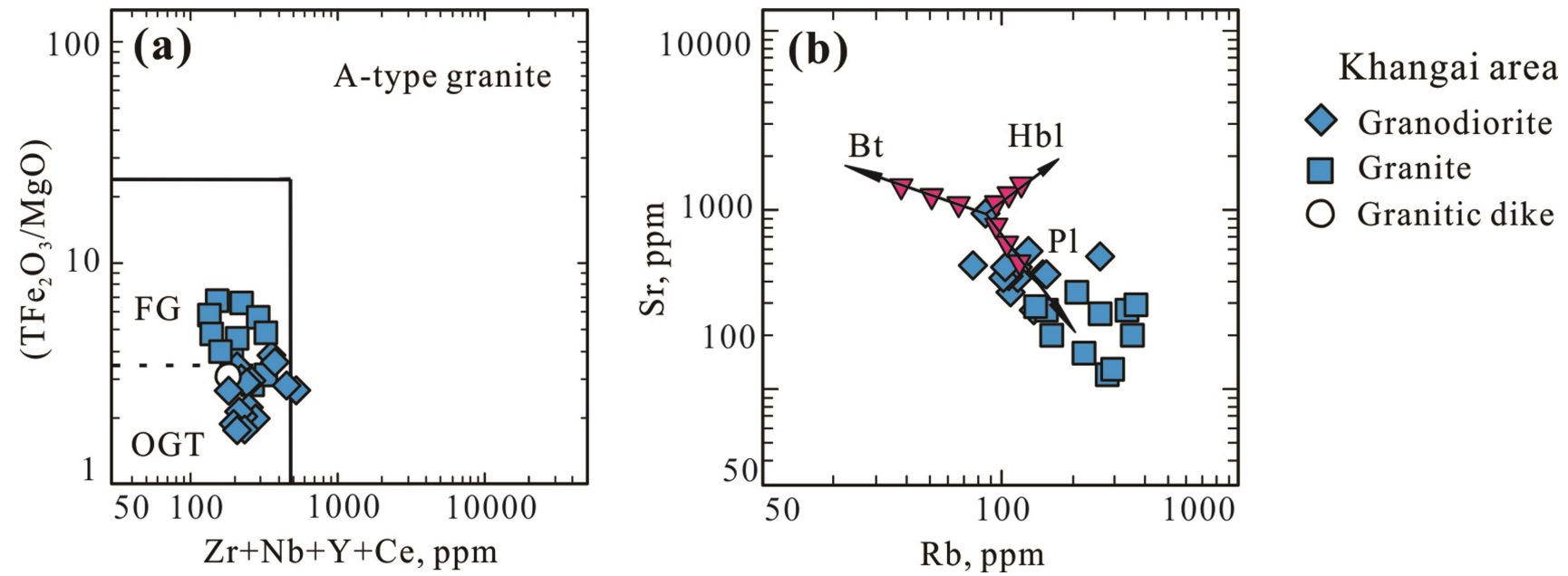

Fig. 11. Diagrams showing granitic rocks from the Khangai area plotted on tectonic discrimination diagrams. (a) $\mathrm{TFe}_{2} \mathrm{O}_{3} / \mathrm{MgO}$ vs. $(\mathrm{Zr}+\mathrm{Nb}+\mathrm{Y}+\mathrm{Ce}$ ) after Whalen et al. (1987) with abbreviations as in Fig. 9. (b) $\mathrm{Rb}$ vs. Sr diagram showing compositional vectors reflecting the fractionation of biotite (Bt), hornblende (Hbl), and plagioclase (Pl) within granitic systems. Each vector reflects 30\% crystallization with pink triangles indicating $10 \%$ fractionation intervals. Partition coefficients used are from Arth (1976) and the initial composition is the same as sample $15082801 \mathrm{~A}$. 
flat HREE patterns for these samples also suggest derivation from a source containing more residual amphibole than garnet (Moyen, 2009). The primitive-mantle-normalized multielement patterns for the biotite granites have positive $\mathrm{Rb}, \mathrm{Th}$, and $\mathrm{U}$, and negative $\mathrm{Ba}, \mathrm{Sr}, \mathrm{Nb}$, $\mathrm{Ta}, \mathrm{P}$, and $\mathrm{Ti}$ anomalies. Depletions in $\mathrm{Nb}, \mathrm{Ta}$, and $\mathrm{Ti}$ are usually indicative of the separation of Ti-bearing phases such as ilmenite and/or rutile (Martin et al. 2005). In addition, the $\mathrm{P}_{2} \mathrm{O}_{5}$ depletions are most likely indicative of the fractionation of apatite together with plagioclase and hornblende as discussed above, and the negative $\mathrm{Eu}$ anomalies within these samples reflect plagioclase fractionation. This suggests that the biotite-hornblende granodiorites and biotite granites were derived from the same magma source, and these granitoids are geochemically similar to coeval granitoids in the Erguna massif, suggesting these magmatic events might be linked (Tang et al., 2015).

238-237 Ma granitoids. The 238-237 Ma pegmatitic granites are silica-rich $\left(\mathrm{SiO}_{2}=71.46\right.$ -78.32 wt. \%) and have high concentrations of the alkali elements. Their $\mathrm{SiO}_{2}$ concentrations negatively correlate with $\mathrm{P}_{2} \mathrm{O}_{5}, \mathrm{CaO}$, and $\mathrm{Al}_{2} \mathrm{O}_{3}$ (Fig. 7) and they have high $\mathrm{TFe}_{2} \mathrm{O}_{3} / \mathrm{MgO}$ and $\mathrm{Ga} / \mathrm{Al}$ values (Fig. 10a, b), all of which suggest that these rocks have undergone significant magmatic differentiation and have A-type granite affinities, as evidenced by their classification as A-type in a $\mathrm{Y}-\mathrm{Nb}-\mathrm{Zr} / 4$ ternary diagram (Fig. 10c). These units also contain elevated concentrations of the HFSE (e.g., $\mathrm{Nb}$ and Y), contrasting with the 269-248 Ma biotite -hornblende granodiorites and biotite granites. They have primitive-mantle-normalized multielement patterns that are characterized by positive $\mathrm{Rb}$, Th, $\mathrm{U}$, and $\mathrm{Pb}$, and negative $\mathrm{Ba}, \mathrm{Sr}$, $\mathrm{P}, \mathrm{Eu}$, and Ti anomalies. These depletions in $\mathrm{Ba}$, $\mathrm{Sr}$, and $\mathrm{Eu}$ are indicative of the fractionation of feldspar, whereas the $\mathrm{P}_{2} \mathrm{O}_{5}$ depletions in these samples are indicative of the fractionation of apatite. However, A-type granites can form in both post-orogenic and anorogenic settings (Bonin, 2007), and it is often difficult to discriminate between A-type and post-orogenic granites, although there are some geological, mineralogical, and chemical differences between these two types of granite (Bonin, 1990). Anorogenic granites are commonly associated with syenite-alkali feldspar syenitenepheline syenite suites and are depleted in $\mathrm{Ba}$ and $\mathrm{Sr}$, but are enriched in Fe. In contrast, postorogenic granites are generally enriched in $\mathrm{Ba}$ and $\mathrm{Sr}$ and commonly have high-K calk-alkaline compositions. The pegmatitic granites in the study area have relatively flat REE patterns, significant negative Eu anomalies, and high-K calk-alkaline compositions. Combining these observations with the absence of associated mafic minerals such as arfvedsonite and aegirine suggests these units represent a post-orogenic suite of magmas that formed by the partial melting of highly fractionated I-type granitic rocks, similar to the post-orogenic granitoids of the Bogd Uul pluton in the Khentii area (Khishigsuren et al., 2012).

\section{Tectonic setting of the granitoids in the Khangai} area.

The 269-248 Ma biotite-hornblende granodiorites are volcanic arc granites (Fig. 9b, c), whereas some of the biotite granites in this area are classified as collision-related granites, most likely reflecting the effects of fractionation and crustal contamination (Pearce et al., 1984). The 269-248 Ma granitoids in the Khangai area are similar to coeval granitic rocks of the Erguna massif (Tang et al., 2015), which consist of a suite of quartz diorites, granodiorites, and monzogranites, all of which have high-K and calc-alkaline affinities. These rocks are also similar to the granitoids in the Khangai area in that they are LILE and LREE enriched, but are depleted in the HFSE and HREE. The 269-248 Ma biotite-hornblende granodiorites in the Khangai area are also similar in composition to representative subduction-related continental arc granitoids of the Sierra Nevada in California, USA (Cecil et al., 2012; Fig. 12). This suggests that the 269-248 Ma magmatism in the Khangai area occurred in an active continental margin setting related to the subduction of the MongolOkhotsk oceanic plate.

The 238-237 Ma pegmatitic granites are classified as A2-type granites, suggesting that they formed in a post-collisional setting rather during intraplate rifting (Fig. 10c). This is 
consistent with the ca. 208 Ma timing of formation of post-collisional granites from the Bogd Uul pluton in the Khentii area (Khishigsuren et al., 2012). All of these data suggest that the Mongol-Okhotsk Ocean had closed by the Triassic at the latest.

\section{Tectonic model for the formation of the Baidrag} and Khangai granitoids

Combining the new field evidence, geochemical, and zircon $\mathrm{U}-\mathrm{Pb}$ geochronological data presented in this study with the results of previous research enables a tectonic model for the formation of the Baidrag and Khangai granitoids to be established (Fig. 13).

a) Initial metamorphism within the Baidrag craton occurred at ca. $1800 \mathrm{Ma}$ (Adachi et al., 2012a). Later (ca. 560-530 Ma) northward subduction of oceanic crust beneath the craton generated adakites as a result of slab melting (Fig. 13a). This adakitic magmatism is consistent with contemporaneous (ca. $540 \mathrm{Ma}$ ) eclogitefacies metamorphism in the lake zone (Štípská et al., 2010). It is also likely that these slab-derived adakitic magmas did not provide enough heat to cause partial melting of the lower crust at this time, as evidenced by a lack of contemporaneous normal arc granites and the record of polyphase metamorphism in this area at ca. 540 Ma (Adachi et al., 2012a).

b) An ocean most likely existed between the Baidrag and Siberian (?) cratons, which started to be subducted beneath the latter at ca. 270-250 Ma. This generated biotitehornblende granodiorite and biotite granite magmas that were emplaced into the Devonian to Carboniferous Khangai Basin (Orolmaa et al., 2008) during the Permian (Fig. 13b).

c) The presence of ca. 240 Ma post-collisional granites in this area is indicative of magmatism related to the closure of the ocean and onset of continental collisional tectonism (Fig. 13c).

\section{CONCLUSIONS}

The new zircon $\mathrm{U}-\mathrm{Pb}$ ages and whole-rock major and trace element data presented in this study allows the following conclusions to be reached:

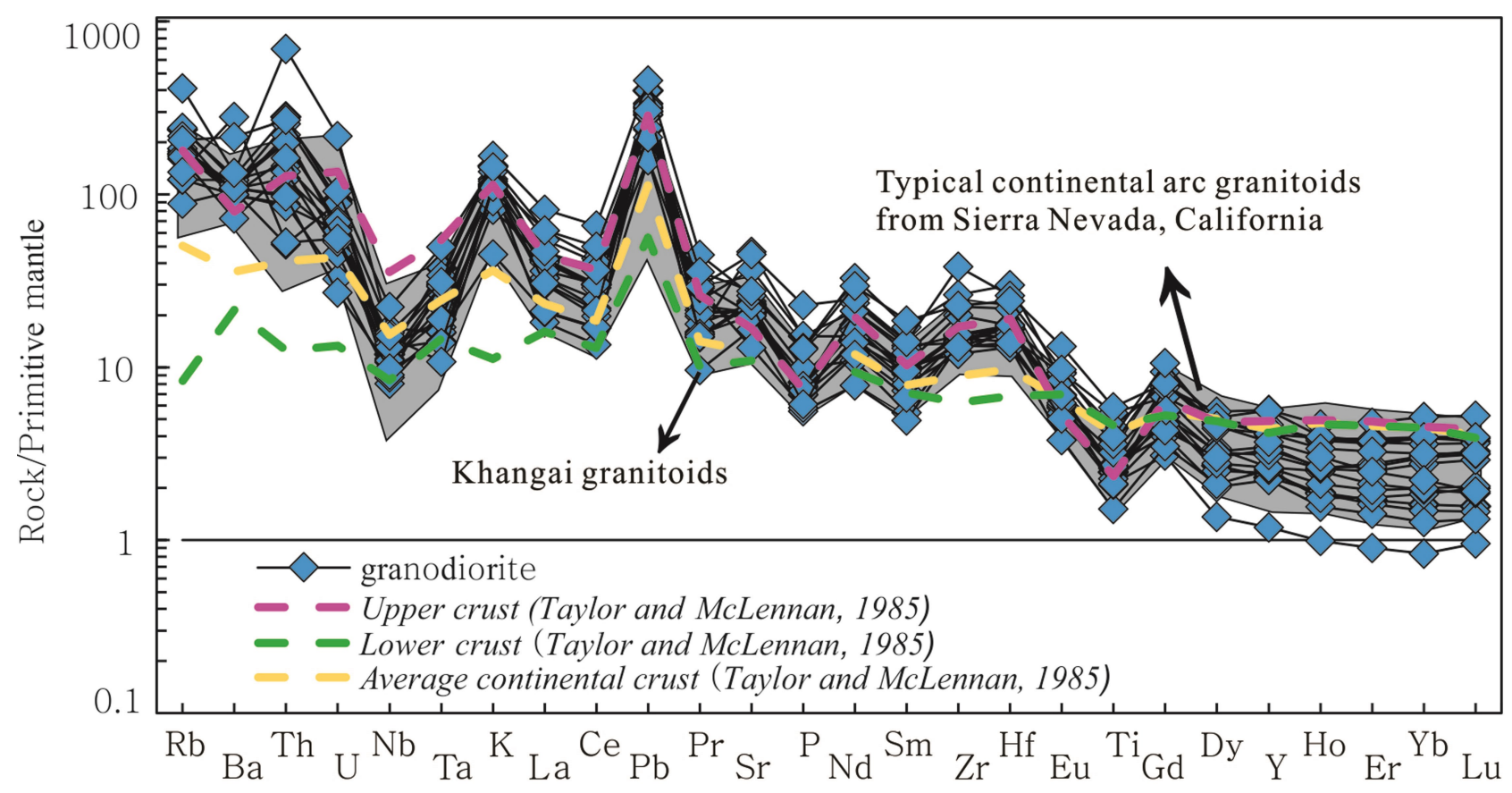

Fig. 12. Primitive-mantle-normalized multi-element patterns showing the composition of biotite-hornblende granodiorites of the Khangai area compared to subduction-related continental arc granitoids from the Sierra Nevada of California (shaded area; Cecil et al., 2012), showing the similarity of the compositions of the granitoids from these two areas. Data are normalized to the primitive mantle composition of Sun and McDonough (1989). 
(a) ca. 560-530 Ma
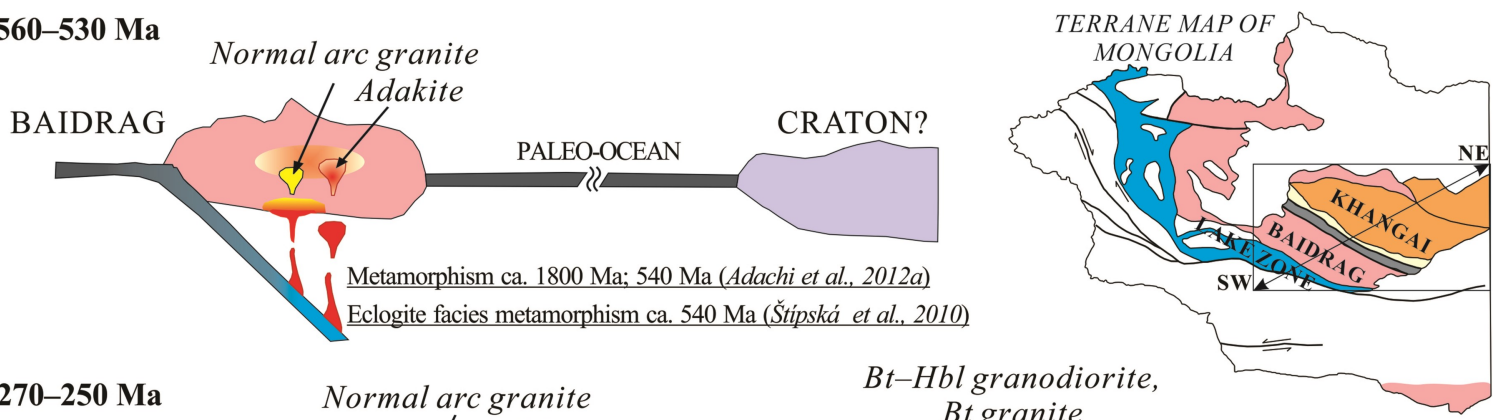

(b) ca. 270-250 Ma

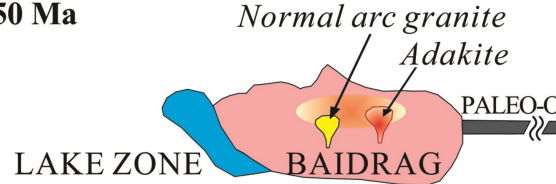

Bt-Hbl granodiorite, Bt granite

KHANGAI BASIN, Dev-Carboniferous (Orolmaa et al., 2008)

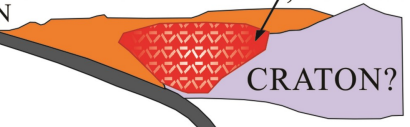

(b) ca. 240 Ma

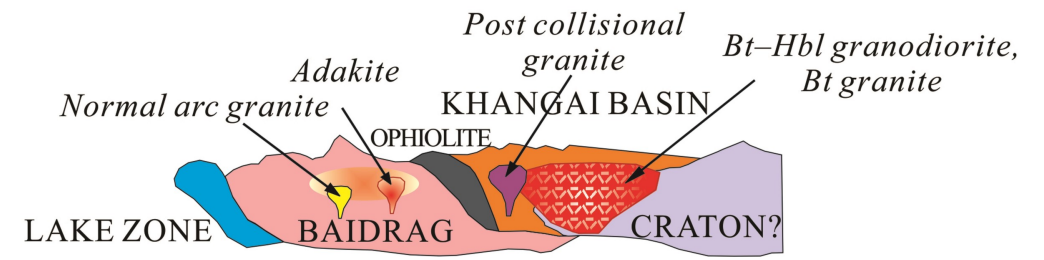

Fig. 13. Model showing the evolution of the study area. (a) Arc-type magmatism in the Baidrag area involving melting of the subducting oceanic slab and lower crust. (b) Arc-type magmatism in the Khangai area, forming biotite-hornblende granodiorite and biotite granite magmas. (c) Closure of the ocean and generation of postcollisional granites. Inset map shows the modern location of each of these terranes (Badarch et al., 2002).

1. Zircon $\mathrm{U}-\mathrm{Pb}$ dating indicates that the magmatic activity in central Mongolia can be broadly divided into three stages that involved the formation of the 564-532 Ma Baidrag granitoids and the 269-248 and 238 -237 Ma Khangai granitoids.

2. The geochemistry of the Baidrag granitoids is indicative of an adakitic and I-type affinity, suggesting that the magmas that formed these granites were derived from a source containing two different types of source material.

3. The Khangai granitoids consist of high-K calc-alkaline granodiorite and granite units with I-type affinities that are associated with a suite of A-type granites.

4. The Baidrag granitoids suggest that arc magmatism occurred in central to southcentral Mongolia at 564-532 Ma.

5. The time gap between the Baidrag and Khangai granitoids may be associated with the development of an ocean, with the associated oceanic plate subsequently subducted beneath the Khangai area, generating voluminous granitic magmas at
269-248 Ma that subsequently formed the Khangai arc granitoids.

6. The closure of this ocean was followed by post-collisional granitoid magmatism at 238$237 \mathrm{Ma}$ as evidenced by the later Khangai granitoids. These granitoids may form the western end of the scattered granitic magmatism at this time within the MOFB.

\section{ACKNOWLEDGEMENTS}

We deeply thank to Professor Sereenen Jargalan and Doctor Boldbaatar Enkhjargal from the School of Geology and Mining Engineering of the Mongolian University of Science and Technology for helpful supports and discussions during field survey. Thanks also go to all of my colleagues within the Central Geological Laboratory of Mongolia and Doctor Demberel Orolmaa at the Institute of Geology of the Mongolian Academy of Sciences for useful comments and discussions. This research and associated MSc project was supported by a Project for Human Resource Development Scholarship from Japanese Grant Aid (JDS), with an endorsement from the Japan 
International Cooperation Agency (JICA), and I would like to express my sincere thanks to the Japanese government for this financial support.

\section{REFERENCES}

Adachi, T., Osanai, Y., Nakano, N., Owada, M., Satish-Kumar, M., Jargalan, S., Boldbaatar, Ch., Yonemura, K., Yoshimoto, A. 2012a. Petrology and geochronology of metamorphic rocks in the Bayankhongor area, the central part of Mongolia. Abstract of Japan Geoscience Union Meeting 2012 (20 to 25th of May), SMP46-P07.

Adachi, T., Osanai, Y., Nakano, N., Owada, M. 2012b. LA-ICP-MS U-Pb zircon and FEEPMA U-Th- $\mathrm{Pb}$ monazite dating of pelitic granulites from the Mt. Ukidake area, Sefuri Mountains, northern Kyushu. Journal of Geological Society, Japan, v. 118, p. 39-52. https://doi.org/10.5575/geosoc.2011.0022

Arth, J.G. 1976. Behaviour of trace elements during magmatic processes: a summary of theoretical models and their applications. Journal of Research of the U.S. Geological Survey, v. 4, p. 41-47.

Badarch, G., Cunningham, W.D., Windley, B.F. 2002. A new terrane subdivision for Mongolia: Implications for the Phanerozoic crustal growth of Central Asia. Journal of Asian Earth Sciences, v. 21, p. 87-104. https://doi.org/10.1016/S1367-9120(02)00017 $-2$

Black, L.P., Kamo, S.L., Allen, C.M., Aleinikoff, J.N., Davis, D.W., Korsch, R.J., Foudoulis, C. 2003. TEMORA1: a new zircon standard for Phanerozoic U-Pb geochronology. Chemical Geology, v. 200, p. 155-170. https://doi.org/10.1016/S0009-2541 (03)00165-7

Bonin, B. 1990. From orogenic to anorogenic settings: evolution of granitoid suites after a major orogenesis. Geological Journal, W.S. Pitcher Special Issue, v. 25, p. 261-270. https://doi.org/10.1002/gj.3350250309

Bonin, B. 2007. A-type granites and related rocks: Evolution of a concept, problems and prospects. Lithos, v. 97(1-2), p. 1-29. https:// doi.org/10.1016/j.lithos.2006.12.007

Buchan, C., Pfänder, J., Kröner, A., Brewer, T.S., Tomurtogoo, O., Tomurhuu, D.,
Windley, B.F. 2002. Timing of accretion and collisional deformation in the Central Asian Orogenic Belt: Implications of granite geochronology in the Bayankhongor Ophiolite Zone. Chemical Geology, v. 192(12), p. 23-45. https://doi.org/10.1016/S00092541(02)00138-9

Castillo, P.R. 2012. Adakite petrogenesis. Lithos, v. 134-135, p. 1-340. https:// doi.org/10.1016/j.lithos.2011.09.013

Cecil, M.R., Rothberg, G.I., Ducea, M.N., Saleeby, J.B., Gehrels, G.E. 2012. Magmatic growth and batholitic root development in the northern Sierra Nevada, California. Geosphere, v. 8(3), p. 592-606.

Chappell, B.W., White, A.J.R. 2001. Two Contrasting Granite Types: 25 Years Later. Australian Journal of Earth Sciences, v. 48(4), p. 489-500. https://doi.org/10.1046/j.14400952.2001.00882.x

Corfu, F., Hanchar, J.M., Hoskin, P.W.O., Kinny, P. 2003. Atlas of Zircon textures. Reviews in Mineralogy and Geochemistry, v. 53 (1), p. 469-500. $\underline{\text { https:// }}$ doi.org/10.2113/0530469

Demoux, A., Kröner, A., Badarch, G., Jian, P., Tomurhuu, D., Wingate, M.T.D. 2009. Zircon Ages from the Baidrag Block and the Bayankhongor Ophiolite Zone: Time Constraints on Late Neoproterozoic to Cambrian Subduction-and Accretion-Related Magmatism in Central Mongolia. The Journal of Geology, v. 117(4), p. 377-397. https:// doi.org/10.1086/598947

Donskaya, T.V., Gladkochub, D.P., Mazukabzov, A.M., De Waele, B., Presnyakov, S.L. 2012. The Late Triassic Kataev volcanoplutonic association in western Transbaikalia, a fragment of the active continental margin of the Mongol-Okhotsk Ocean. Russian Geology and Geophysics, v. 53(1), p. 22-36. https://doi.org/10.1016/ j.rgg.2011.12.002

Defant, M.J., Drummond, M.S., 1990. Derivation of some modern arc magmas by melting of young subducted lithosphere. Nature, v. 347, p. 662-665. https:// doi.org/10.1038/347662a0

Drummond, M.S., Defant, M.J., Kepezhinskas, P.K. 1996. Petrogenesis of slab-derived 
trondhjemite-tonalite-dacite/adakite magmas. Transactions of the Royal Society of Edinburgh. Earth Sciences, v. 87, p. 205-215. https://doi.org/10.1017/S0263593300006611

Eby, G.N. 1992. Chemical subdivision of the Atype granitoids: Petrogenetic and tectonic implications. Geology, v. 20(7), p. 641-644. https://doi.org/10.1130/0091-7613(1992) $020<0641:$ CSOTAT $>2.3 . \mathrm{CO} ; 2$

Griffin, W.L., Powell, W.J., Pearson, N.J., O'Reilly, S.Y. 2008. GLITTER: Data reduction software for laser ablation ICP-MS. Mineralogical Association of Canada Short Course, Series 40. Appendix A2, p. 308-311.

Harris, N.B.W., Pearce, J.A., Tindle, A.G. 1986. Geochemical characteristics of collision-zone magmatism. Geological Society, London, Special Publications, v. 19(1), p. 67-81. https://doi.org/10.1144/ GSL.SP.1986.019.01.04

Jahn, B.M., Capdevila, R., Liu, D., Vernon, A.,Badarch, G. 2004. Sources of Phanerozoic granitoids in the transect BayanhongorUlaanBaatar, Mongolia: Geochemical and Nd isotopic evidence, and implications for Phanerozoic crustal growth. Journal of Asian Earth Sciences, v. 23(5), p. 629-653. https:// doi.org/10.1016/S1367-9120(03)00125-1

Jackson, S.E., Pearson, N.J., Griffin, W.L., Belousova, E.A. 2004. The application of laser ablation-inductively coupled plasma mass spectrometry to in situ U-Pb zircon geochronology. Chemical Geology, v. 211, p. 47-69.https://doi.org/10.1016/ j.chemgeo.2004.06.017

Jian, P., Kröner, A., Windley, B.F., Shi, Y., Zhang, F., Miao, L., Liu, D. 2010. Zircon ages of the Bayankhongorophiolite mélange and associated rocks: Time constraints on Neoproterozoic to Cambrian accretionary and collisional orogenesis in Central Mongolia. Precambrian Research, v. 177(1-2), p. 162180.https://doi.org/10.1016/ j.precamres.2009.11.009

Kay, R.W., Kay, S. Mahlburg., 1991. Creation and destruction of lower continental crust. Geologische Rundschau, v. 80(2), p. 259-278. https://doi.org/10.1007/BF01829365

Kelty, T.K., Yin, A., Dash, B., Gehrels, G.E., Ribeiro, A.E. 2008. Detrital-zircon geochronology of Paleozoic sedimentary rocks in the Khangai-Khentii basin, northcentral Mongolia: Implications for the tectonic evolution of the Mongol-Okhotsk Ocean in central Asia. Tectonophysics, v. 451 (1-4), p. 290-311. https://doi.org/10.1016/ j.tecto.2007.11.052

Khishigshuren, S., Ochir, G., Danzan, C. 2012. Origin of the Early Mesozoic Bogd Uul granite pluton, Ulaanbaatar area, Mongolia, Bulletin of Nagoya University Museum, v. 28, p. 45-59.

Kitano, I., Osanai, Y., Nakano, N., Adachi, T., Yoshimoto, A., 2014. Rapid techniques for zircon separation and the application for $\mathrm{U}-\mathrm{Pb}$ dating. Bulletin of the Graduate School Social and Cultural Studies, Kyushu University, v. 20, p. 1-10. (in Japanese with English abstract).

Kröner, A., Demoux, A., Zack, T., RojasAgramonte, Y., Jian, P., Tomurhuu, D., Barth, M. 2011. Zircon ages for a felsic volcanic rock and arc-related early Palaeozoic sediments on the margin of the Baidrag microcontinent, central Asian orogenic belt, Mongolia. Journal of Asian Earth Sciences, v. 42(5), p. 1008-1017. https://doi.org/10.1016/ j.jseaes.2010.09.002

Ludwig, K.R. 2008. User's Manual for Isoplot 3.70: a geochronological toolkit for Microsoft Excel. Berkeley Geochronology Center Special Publication, v. 4, p. 1-77.

Martin, H. 1999. Adakitic Magmas: Modern Analogues of Archaean Granitoids. Lithos, v. 46(3), p. 411-29. https://doi.org/10.1016/ S0024-4937(98)00076-0

Martin, H., Smithies, R.H., Rapp, R., Moyen, J.F., Champion, D. 2005. An Overview of Adakite, Tonalite-TrondhjemitenGranodiorite (TTG), and Sanukitoid: Relationships and Some Implications for Crustal Evolution. Lithos, v. 79, p. 1-24. https://doi.org/10.1016/j.lithos.2004.04.048

Moyen, J.F. 2009. High $\mathrm{Sr} / \mathrm{Y}$ and $\mathrm{La} / \mathrm{Yb}$ ratios: the meaning of the "adakitic" signature. Lithos, v. 112, p. 556-574. https:// doi.org/10.1016/j.lithos.2009.04.001

Nakano, N., Osanai, Y., Adachi, T., Yonemura, K., Yoshimoto, A., Setiawan, N. 2012. A rapid technique for quantitative determination 
of major, trace and rare earth elements in low dilution glass bead using XRF and LA-ICPMS. Bulletin of Graduate School of Social and Cultural Studies Kyushu University, v. 17, p. 81-94.

Orolmaa, D., Erdenesaihan, G., Borisenko, A.S., Fedoseev, G.S., Babich, V.V., Zhmodik, S.M. 2008. Permian-Triassic granitoid magmatism and metallogeny of the Khangain (central Mongolia). Russian Geology and Geophysics, v. 49(7), p. 534-544. https://doi.org/10.1016/ j.rgg.2008.06.008

Paces, J.B., Miller, J.D.J. 1993. U-Pb ages of Duluth Complex and related mafic intrusions, northeastern Minnesota: geochronological insights to physical, petrogenetic, paleomagnetic, and tectonomagmatic processes associated with the $1.1 \mathrm{Ga}$ midcontinent rift system. Journal of Geophysical Research, v. 98, p. 13997-14013. https://doi.org/10.1029/93JB01159

Pearce, J.A., Harris, N.B.W., Tindle, A.G. 1984. Trace element discrimination diagrams for the tectonic interpretation of granitic rocks. Journal of Petrology, v. 25(4), p. 956-983. https://doi.org/10.1093/petrology/25.4.956

Purevjav, N., Roser, B. 2012. Geochemistry of Devonian-Carboniferous clastic sediments of the Tsetserlegterrane, Khangai Basin, Central Mongolia: Provenance, source weathering, and tectonic setting. Island Arc, v. 21(4), p. 270-287. $\quad$ https://doi.org/10.1111/j.14401738.2012.00821.x

Richards, J.P., Kerrich, R. 2007. Adakite-like rocks: their diverse origins and questionable role in metallogenesis. Economic Geology, v. 102, p. 537-576. https://doi.org/10.2113/ gsecongeo.102.4.537

Štípská, P., Schulmann, K., Lehmann, J., Corsini, M., Lexa, O., Tomurhuu, D. 2010. Early Camberian eclogites in SW Mongolia: evidence that the Palaeo-Asian Ocean suture extends further east than expected. Journal of Metamorphic Petrology, v. 28, p. 915-933. https://doi.org/10.1111/j.15251314.2010.00899.x

Sun, S.S., McDonough, W.F. 1989. Chemical and isotopic systematics of oceanic basalt: implications for mantle composition and processes. In: Saunders, A.D., Norry, M.J.
(Eds.), Magmatism in the Ocean Basins. Geological Society, London, Special Publications, v. 42, p. 528-548. https:// doi.org/10.1144/GSL.SP.1989.042.01.19

Tang, J., Xu, W.L., Wang, F., Zhao, S., Wang, W. 2015. Early Mesozoic southward subduction history of the Mongol-Okhotsk oceanic plate: Evidence from geochronology and geochemistry of Early Mesozoic intrusive rocks in the Erguna Massif, NE China. Gondwana Research, v. 31, p. 218-240. https://doi.org/10.1016/j.gr.2014.12.010

Takahashi, Y., Arakawa, Y., Oyungerel, S., Naito, K. 2000. Geochronological data of granitoids in the Bayankhongor area, central Mongolia. Bulletin of the Geological survey of Japan, v. 51 (5), p. 167-174.

Taylor, S.R., McLennan, S.M., 1985. The Continental Crust: Its Composition and Evolution. Blackwell Scientific Publication, Carlton, $312 \mathrm{p}$.

Tomurtogoo, O., ed. 1998. Geological map of Mongolia: Mineral Resources Authority of Mongolia, Mongolian Academy of Sciences, Ulaanbaatar, scale 1:100,000, CD-ROM (with English summary).

Windley, B.F., Alexeiev, D., Xiao, W., Kröner, A., Badarch, G. 2007. Tectonic models for accretion of the Central Asian Orogenic Belt. Journal of the Geological Society, v. 164, p. 31-47.https://doi.org/10.1144/0016-76492006 $-022$

Whalen, J.B., Currie, K.L., Chappell, B.W. 1987. A-type granites: geochemical characteristics, discrimination and petrogenesis. Contributions to Mineralogy and Petrology, v. 95(4), p. 407-419. https:// doi.org/10.1007/BF00402202

Zhang, Y., Sun, M., Yuan, C., Xu, Y., Long, X., Tomurhuu, D., He, B. 2015. Magma mixing origin for high $\mathrm{Ba}-\mathrm{Sr}$ granitic pluton in the Bayankhongor area, central Mongolia: Response to slab roll-back. Journal of Asian Earth Sciences, v. 113, p. 353-368. https:// doi.org/10.1016/j.jseaes.2014.11.029

Zorin, Y.A. 1999. Geodynamics of the western part of the Mongolia-Okhotsk collisional belt, Trans-Baikal (Russia) and Mongolia. Tectonophysics, v. 306, p. 33-56. https:// doi.org/10.1016/S0040-1951(99)00042-6 